Research Report No. 1/2010

\title{
Transnational Legal Pluralism
}

Peer Zumbansen

Osgoode Hall Law School of York University, PZumbansen@osgoode.yorku.ca

Follow this and additional works at: http://digitalcommons.osgoode.yorku.ca/clpe

\section{Recommended Citation}

Zumbansen, Peer, "Transnational Legal Pluralism" (2010). Comparative Research in Law \& Political Economy. Research Paper No. $1 / 2010$.

http://digitalcommons.osgoode.yorku.ca/clpe/70 


\title{
Comparative Research in Law \& Political Economy
}

\author{
Peer Zumbansen
}

\section{Transnational Legal Pluralism}

EDITORS: Peer Zumbansen (Osgoode Hall Law School, Toronto, Director, Comparative Research in Law and Political Economy, York University), John W. Cioffi (University of California at Riverside), Nassim Nasser (Osgoode Hall Law School, Toronto, Production Editor) 


\title{
CLPE Research Paper 01/2010
}

Vol. 06 No. 01 (2010)

\section{Peer Zumbansen}

\section{Transnational Legal Pluralism}

\begin{abstract}
This paper draws out the analogies and connections between long-standing legal sociological insights into pluralistic legal orders and present concerns with the fragmentation of law outside of the nation state. Within the nation-state, the discovery of legal pluralism inspired a larger contestation of concepts of legal formalism, of the alleged unity of the legal order and of the hierarchy of norms against the background of a consistently advancing process of constitutionalization. This research heightened regulators' sensitivity to blind spots and exclusionary dynamics in the design of rights, leading inter alia to wide-ranging efforts to render more effective access to justice, legal aid and legal representation. Another important consequence concerned an increased awareness of different levels and sites of norm-creation in various societal areas. Much of this is mirrored by today's quest for a just, democratic and equitable global legal order, for example in the debate about 'fragmentation of international law' or 'global administrative law'. But, while the legal pluralism debate largely unfolded in the context (and contestation) of relatively mature legal orders and institutions, such institutional frameworks and safeguards are largely absent on the international plane. As a result, the emergence of numerous norm-setting agencies, specialized courts and tribunals and regulatory networks are perceived as obstacles or impediments to the creation of a sound legal order on a global scale, rather than as inherent traits of an evolving legal order.
\end{abstract}

In order to grasp the increasingly transterritorial nature of regulatory governance it is necessary to revisit the arguments in support of legal pluralism and, in particular, the legal pluralist critique of the association of law with the state. On that basis, it becomes possible to read the currently dominant narrative of the 'end of law' in an era of globalisation in a different light. Rather than describing the advent of globalisation as an end-point of legal development, the transnational perspective seeks to deconstruct the various law-state associations by understanding the evolution of law in relation and response to the development of 'world society'. The currently lamented lack of democratic accountability, say, in international economic governance, can then be perceived as a further consequence in a highly differentiated and de-territorialized society. The paper thus rejects the attempts by lawyers to re-align transnational governance actors with traditional concepts of the state or of civil society and, instead, contrasts them with various advances in sociology and anthropology with regard to the evolution of 'social norms' and 'spaces' of governance and regulation. These perspectives effectively challenge present attempts to conceptualize a hierarchically structured global legal order. This article's proposed concept of 'transnational legal pluralism' [TLP] goes beyond Philip Jessup's 1956 idea of 'transnational law', through which he sought to both complement and challenge Public and Private International Law. TLP brings together insights from legal sociology 
and legal theory with research on global justice, ethics and regulatory governance to illustrate the transnational nature of law and regulation, always pushing against the various claims to legal unity and hierarchy made over time.

Forthcoming in (2010) Vol. 1 No. 2 Transnational Legal Theory, 141-189.

Keywords: Legal Pluralism, Fragmentation of law, Regulatory Governance, Transnational Law, Private Governance Regimes, Regulatory Networks, Rough Consensus and Running Code

JEL classification: $\mathrm{K} 20$, K 22, K 33

\section{Peer Zumbansen \\ Professor of Law}

Canada Research Chair in Transnational Economic Governance and Legal Theory Osgoode Hall Law School, York University, Toronto.

Director, Critical Research Laboratory in Law \& Society www.criticalresearchlab.org

Email: Pzumbansen@osgoode.yorku.ca 


\section{Transnational Legal Pluralism}

Peer Zumbansen*

\section{INTRODUCTION}

One of the distinctive features of today's legal theoretical work on global governance is the recurring frustration over and problematization of the absence of stable institutions of normcreation and enforcement outside of the nation state. While the discrepancy between the weight and urgency of border-crossing regulatory challenges - such as climate change, migration and security on the one hand and the existing institutional and normative framework, on the other - arguably lies at the bottom of this malcontent, global governance must address other concerns as well. One such concern has to do with the ambiguity of the concept and the term depicting it. 'Global' 'governance' alludes to two transformations, namely a shift from government to governance and to a counting of time 'before' and 'after' globalisation. Approaching global governance from this starting point, however, carries particular risks of juxtaposing inadequately depicted states and constellations of legal and political order.

Related narratives are often informed by accounts of globalisation as marking a moment of loss of something that was there before. As will be discussed in more detail later, this demarcation of before and after inappropriately idealizes and petrifies the before but also limits the range of institutional and normative imagination applicable to the after. This has significant consequences, for example, when we are confronted with the alleged loss of legal 'unity', 'certainty' or, 'hierarchy' in the global arena as opposed to the nation state, which in turn is celebrated as an ideal space that now has become lost (or, at least, radically undermined or diminished) and, thus, ill-suited to the demands of a globalised world. The distinction between the 'before' and the 'after' of globalisation also has a tremendous impact on the normative evaluation of what was and what is to come, something that has become extremely important for the critique of colonialism and so-called post-colonialism ${ }^{1}$ and which, in turn, has been a crucial source of critical scholarship in international law. ${ }^{2}$

\footnotetext{
* Professor of Law, Canada Research Chair, Osgoode Hall Law School. 2009-2010, Visiting Professor University College Dublin, School of Law. Pzumbansen@osgoode.yorku.ca

${ }^{1}$ Makau Mutua, Human Rights: A Political and Cultural Critique (University of Pennsylvania Press, Philadelphia, PA 2002) Preface, $x$ : "Just imagine what the rejection of my past meant. The colonial dispensation had created images of my past. Barbaric, primitive, tribal, savage, satanic, uncultured, uneducated. It was a past without a history." In this vein, see also Dipesh Chakrabarty, Provincializing Europe. Postcolonial Thought and Historical Difference, 2nd ed. [orig. 2000] (Princeton University Press, Princeton, NJ 2007), and Partha Chatterjee, The Nation and Its Fragments. Colonial and Postcolonial Histories (Princeton University Press, Princeton, NJ 1993).

${ }^{2}$ Antony Anghie, 'The Evolution of International Law: colonial and postcolonial realities' (2006) 27 Third World Quarterly 739-753; Ruth Buchanan, 'Writing Resistance Into International Law' (2008) 10 International Community
} 
From a different angle, global governance raises serious concerns among critical legal scholars, who understandably fear the fast emergence and consolidation of an all-encompassing regulatory framework that is driven more by alleged needs to 'react', to 'monitor', to 'facilitate' and to 'moderate' global activity than by a continued engagement with a political theory of law in a pluralistic and divided world. Where 'good governance' then turns into a label and a metatheoretical justification for ongoing processes of economic globalisation, alternative proposals, geared towards reneweds critiques of property ${ }^{3}$ and human rights ${ }^{4}$ and towards the development of empowering, pluralistic transnational communities ${ }^{5}$ and forums, ${ }^{6}$ face serious obstacles.

In light of these complexities of overlapping and conflicting accounts, the disciplinary field of global governance offers an important opportunity to gain new and further insights into the building blocks of an emerging legal, political and economic order. The struggle with the absence of 'world government' is undeniably a struggle - over the form and legitimacy of - any - government itself. As such, current inquiries into the role of the state and the nature of legal regulation are charged with the translation of an extremely rich repository of rights critique, 'law and society' scholarship, 'law and economics' analysis, and legal anthropology into the discourses unfolding under the umbrella of an interdisciplinary study of transnational regulatory regimes. Such a research agenda develops against the background of the 'antipositivist' origins of legal pluralism ${ }^{7}$, which eventually evolved into a highly differentiated and

Law Review 1-10; Obiora Chinedu Okafor, 'Critical Third World Approaches to International Law (TWAIL): Theory, Methodology, or Both?' (2008) 10 International Community Law Review 371-378.

${ }^{3}$ Robert L. Hale, 'Coercion and Distribution in a Supposedly Non-Coercive State' (1923) 38 Political Science Quarterly 470-494; Kerry Rittich, Recharacterizing Restructuring. Law, Distribution and Gender in Market Reform (The Erik Castrén Institute Monographs on International Law and Human Rights, Kluwer Law International, The Hague 2002); Fleur Johns, 'Performing Power: The Deal, Corporate Rule, and the Constitution of Global Legal Order' (2007) 34 Journal of Law and Society 116-138

${ }^{4}$ Issa G. Shivji, 'Constructing a New Rights Regime: Promises, Problems and Prospects' (1999) 8 Social \& Legal Studies 253-276; Issa G. Shivji, 'Human Rights and Development: A Fragmented Discourse' in Peer Zumbansen and Ruth Buchanan (eds), Law in Transition: Human Rights, Development and Transitional Justice (Hart Publishing, Oxford, UK/Portland, OR 2010); Sundhya Pahuja, 'Rights as Regulation: The Integration of Development and Human Rights' in Bronwyn Morgan (ed) The Intersection of Rights and Regulation (Ashgate, London 2008)

${ }^{5}$ Roger Cotterrell, 'Transnational Communities and the Concept of Law' (2008) 21 Ratio Juris 1-18; Roger Cotterrell, 'Spectres of Transnationalism: Changing Terrains of Sociology of Law' (2009) 36 Journal of Law and Society $481-500$

${ }^{6}$ Boaventura de Sousa Santos, 'The World Social Forum and the Global Left' (2008) 36 Politics \& Society 247-270; David Kennedy, 'Challenging Expert Rule: The Politics of Global Governance' (2005) 27 Sydney Law Review 1-24

${ }^{7}$ Richard Ashby Wilson, 'Tyrannosaurus Lex: The Anthropology of Human Rights and Transnational Law' in Mark Goodale and Sally Engle Merry (eds), The Practice of Human Rights: Tracking Law Between the Global and the Local (Cambridge University Press, Cambridge, UK 2006), 345 
empirically driven analysis of co-existing and overlapping regulatory regimes. ${ }^{8}$ The emergence of 'governance studies' ${ }^{9}$ and the increasingly influential study of law through a regulatory lens ${ }^{10}$ testify to an important widening and deepening of the legal analytical apparatus. Seen in this light, the present obsession with the alleged novelty of a 'global' legal and political order has direct ties to preceding contestations of welfare state governments and their aftermaths in the last two decades, including a significant functionalisation of regulatory policies and legal principles. ${ }^{11}$ Accordingly, much needed inquiries into previous experiences with rights regimes are fuelled by grave concerns over democratic representation ${ }^{12}$ but remaintorn between references to state-to-state relations and a concern with global 'citizens' ${ }^{13}$, as well as over the politics of (domestic) hard and (global) soft laws ${ }^{14}$ and the nature of rights on a global scale. ${ }^{1516}$

${ }^{8}$ Sally Engle Merry, 'Anthropology, Law, and Transnational Processes' (1992) 21 Annual Review of Anthropology 357-379; Sally Engle Merry, 'New Legal Realism and the Ethnography of Transnational Law' (2006) 31 Law \& Soc Inquiry 975-995; Gregory Shaffer and Victoria Nourse, 'Varieties of New Legal Realism: Can A New World Order Prompt A New Legal Theory?' (2009) 61 Cornell Law Review 61-137

${ }^{9}$ See eg, Scott Burris, Michael Kempa and Clifford Shearing, 'Changes in Governance: A Cross-Disciplinary Review of Current Scholarship' (2008) 41 Akron Law Review 1-66.

${ }^{10}$ Colin Scott, 'Regulation in the Age of Governance: The Rise of the Post Regulatory State' in Jacint Jordana and David Levi-Faur (eds), The Politics of Regulation: Institutions and Regulatory Reforms for the Age of Governance (Edward Elgar, Cheltenham 2004); Colin Scott, 'Regulatory Governance and the Challenge of Constitutionalism' (2010) EUI Working Papers Robert Schuman Centre for Advanced Studies, Private Regulation Series-02 http://ucdie.academia.edu/documents/0093/9406/RSCAS_2010_0007.pdf; see also Bronwen Morgan and Karen Yeung, An Introduction to Law and Regulation. Texts and Materials (Cambridge University Press, Cambridge, UK 2007).

${ }^{11}$ Orly Lobel, 'The Renew Deal: The Fall of Regulation and the Rise of Governance in Contemporary Legal Thought' (2004) 89 Minnesota Law Review 342-469; Peer Zumbansen, 'Law After the Welfare State: Formalism, Functionalism and the Ironic Turn of Reflexive Law' (2008) 56 American Journal of Comparative Law 769-805

12 David Held, 'Democratic Accountability and Political Effectiveness from a Cosmopolitan Perspective' (2004) 39 Government and Opposition 364-391; David Held, 'Reframing Global Governance: Apocalypse Soon or Reform!' in David Held and Anthony McGrew (eds), Globalization Theory Approaches and Controversies (Polity, London 2007); Regina Kreide, 'The Ambivalence of Juridification. On Legitimate Governance in the International Context' (2009) 2 Global Justice: Theory Practice Rhetoric 18-34

${ }^{13}$ For an insightful discussion, see Rainer Forst, 'Towards a Critical Theory of Transnational Justice' in Thomas Pogge (ed) Global Justice (Blackwell Publishing, Malden, MA 2001).

${ }^{14}$ Walter Mattli and Ngaire Woods, 'In Whose Benefit? Explaining Regulatory Change in Global Politics' in Walter Mattli and Ngaire Woods (eds), The Politics of Global Regulation (Cambridge University Press, Cambridge, UK 2009)

${ }^{15}$ Sundhya Pahuja, 'Rights as Regulation: The Integration of Development and Human Rights' in Bronwyn Morgan (ed) The Intersection of Rights and Regulation (Ashgate, London 2008); Fleur E. Johns, 'Global Governance: An Heretical History Play' (2004) 4 Global Jurist Advances Art. 3 (http://ssrn.com/abstract=603232), 11, 29, 37: “The space of global governance, as described in these writings [referencing work by John Coffee Jr., Richard Falk, Anne- 
Finally, the competing assertions of market regulation, before and since the unfolding of the global financial and economic crisis that began in $2007^{17}$, call for a renewed assessment of the legal nature of markets, long ago scrutinized by Legal Realist scholars ${ }^{18}$ as well as of the particular forms of legal and non-legal regulation that remain at the centre of law and society $^{19}$ scholarship and studies of 'legal pluralism'. ${ }^{20}$ What has become increasingly recognized is the fact that such inquiry cannot remain confined to a discipline or field on its own: branches of economics as well as a wide range of 'social sciences' have been called upon to contribute to the emergence of a more layered and more differentiated concept of 'regulatory governance'. ${ }^{21}$

Marie Slaughter and others, PZ], is a realm aspiring to be one of coherence and predestination. It is a space in which earthly divisions are to melt away before the final judgment of the market or the universal decrees of human rights. In this domain, the actions of governments, corporations, laborers, employers, even refugees are fused into pre-inscribed patterns of convergence." See also Joseph Raz, 'Human Rights in the Emerging World Order' (2010) 1 Transnational Legal Theory 31-47.

${ }^{16}$ See, for example, Duncan Kennedy, 'The Critique of Rights in Critical Legal Studies' in Wendy Brown and Janet Halley (eds), Left Legalism/Left Critique (Duke University Press, Durham, NC 2002); see also Conor Gearty, Can Human Rights Survive? (2005 Hamlyn Lectures) (Cambridge University Press, Cambridge, UK 2006), in particular ch. 3. Still a very insightful critique is provided by Crawford Brough Macpherson, 'The Rise and Fall of Economic Justice' (1987) in: Macpherson, The Rise and Fall of Economic Justice, and other Essays The role of state, class and property in twentieth-century democracy 1-20, in particular ch. 2: 'Problems of Human Rights in the Late Twentieth Century'.

${ }^{17}$ See eg, Joseph E. Stiglitz, Freefall. America, Free Markets and the Sinking of the World Economy (W.W. Norton \& Co., New York 2010), and Christian Marazzi, The Violence of Financial Capitalism (Edizioni Casagrande, Bellinzona, Switzerland 2010).

18 Robert L. Hale, 'Coercion and Distribution in a Supposedly Non-Coercive State' (1923) 38 Political Science Quarterly 470-494; Morris R. Cohen, 'Property and Sovereignty' (1927) 13 Cornell Law Quarterly 8-30

${ }^{19}$ Lawrence M. Friedman, 'Coming of Age: Law and Society Enters an Exclusive Club' (2005) Annual Review of Law and Social Sciences 1-16

${ }^{20}$ Sally Engle Merry, 'Legal Pluralism' (1988) 22 Law \& Society Review 869-901; Harry W. Arthurs, Without the Law: Administrative Justice and Legal Pluralism in Nineteenth Century England (University of Toronto Press, Toronto 1988); Derek McKee, 'Review Essay - Context and Commitment: A Pluralist Perspective on the Paradox of Law (On Melissaris' Ubiquitous Law)' (2010) 11 GERMAn LAW JOURNAL 573-584.

21 Oliver E Williamson, The Economics of Governance, Nobel Prize Lecture 2009, available at: http://nobelprize.org/nobel prizes/economics/laureates/2009/williamson-lecture.html; see also Oliver E. Williamson, 'The Economics of Governance' (2005) 95 American Economic Review 1-18; Colin Scott, 'Regulatory Governance and the Challenge of Constitutionalism' (2010) EUI Working Papers Robert Schuman Centre for Advanced Studies, Private Regulation Series-02 http://ucdie.academia.edu/documents/0093/9406/RSCAS_2010_0007.pdf; Peer Zumbansen and Gralf-Peter Calliess, 'Law, 
In light of these preliminary observations, the paper aims to draw out the analogies and connections between long-standing legal sociological insights into pluralistic legal orders and present concerns with the 'fragmentation' of law outside of the nation state to show that the focus on law 'before' and 'after' globalisation misses the point. In the context of the nation state and well before the before/after-globalisation optic took hold, legal pluralism had contributed to a fundamental contestation of legal formalism and of the alleged unity and hierarchical structure of the nation state legal order. This research heightened regulators' sensitivity to blind spots and exclusionary dynamics in the design of rights, leading inter alia to wide-ranging efforts to render more effective the access to justice, to legal aid and legal representation. ${ }^{22}$ Another important consequence of legal pluralist research concerned an increased awareness of different levels and sites of norm-creation ${ }^{23}$, work that remains among the central catalysts for a fast-growing regulatory theory literature in law in present times. The ideological battles waged over the basis and limits of rights, over redistribution and over democratic participation naturally cross the boundaries of nation states - in both directions. ${ }^{24}$ Much of this is mirrored by today's quest for a just, democratic and equitable global legal order as reflected, for example, in the debate about the 'fragmentation of international law' ${ }^{25}$ or the aspirations - and limitations - of a 'global administrative law' ${ }^{26}$ But, while the legal pluralism debate had a strong impact in the context and through the contestation of relatively mature

Economics and Evolutionary Theory: State of the Art and Interdisciplinary Perspectives' in Peer Zumbansen and Gralf-Peter Calliess (eds), Law, Economics and Evolutionary Theory (Edward Elgar, Cheltenham, UK 2010).

${ }^{22}$ Marc Galanter, 'Why the 'Haves' Come Out Ahead: Speculations on the Limits of Legal Change' (1974) 9 Law \& Society Rev 95-160.

${ }^{23}$ See only Robert M. Cover, 'Nomos and Narrative' (1983) 97 Harvard Law Review 4-68.

${ }^{24}$ Gerald Epstein, 'International Capital Mobility and the Scope for National Management' in Robert Boyer and Daniel Drache (eds), States Against Markets: the limits of globalization (Routledge, London 1998); Daniela Caruso, 'Private Law and State-Making in the Age of Globalization' (2006) 39 New York University Journal of International Law \& Politics 1-74

${ }^{25}$ Martti Koskenniemi and Paivi Leino, 'Fragmentation of International Law? Postmodern Anxieties' (2002) 15 Leiden Journal of International Law 553; Andreas Fischer-Lescano and Gunther Teubner, 'Regime-Collisions: The Vain Search for Legal Unity in the Fragmentation of Global Law' (2004) 25 Michigan J Int'I L 999-1046

${ }^{26}$ Nico Krisch, Benedict Kingsbury and Richard B. Stewart, 'The Emergence of Global Administrative Law' (2005) 68 Law and Contemporary Problems 15; B.S. Chimni, 'Cooption and Resistance: Two Faces of Global Administrative Law' (2005) IIL International Law and Justice Working Papers 2005/16 ; Carol Harlow, 'Global Administrative Law: The Quest for Principles and Values' (2006) 17 European Journal of International Law 187-214; Susan Marks, 'Naming Global Administrative Law' (2006) 37 New York University Journal of International Law and Politics 9951001 
legal orders and institutions ${ }^{27}$, such institutional frameworks and safeguards are largely absent on the international plane. Accordingly, the emergence of numerous norm-setting agencies, specialized courts and tribunals and regulatory networks can be perceived either as obstacles or impediments to the creation of a sound legal order on a global scale or as inherent traits of an evolving legal order. ${ }^{28}$

In order to grasp the increasingly transterritorial nature of regulatory governance it is necessary to revisit the arguments in support of legal pluralism and, in particular, the legal pluralist critique of law's association with the state. On that basis, it becomes possible to read the currently dominant narrative of the 'end of law' in an era of globalisation in a different light. Rather than describing the advent of globalisation as an end-point of legal development, a transnational perspective seeks to deconstruct the various law-state associations by understanding the evolution of law in relation and response to the development of 'world society', a society understood as non-territorially confined, functionally differentiated and constituted by the co-evolution of conflicting societal rationalities. The decisive feature of world society is the impossibility of devising one convincing meta-theory of political governance. ${ }^{29}$ Instead, its contours only become apparent through an incessant confrontation of particular, functionally differentiated rationalities with a concept of society that remains embedded in a dualist conception of public and private, state and market. On that basis, the lack of democratic accountability, say, in international economic governance ${ }^{30}$, can then be perceived as lying squarely in between the further accentuated evolution of a highly differentiated and deterritorialized society on the one hand and a continued quest for (global) justice on the other. This suggests a certain scepticism towards attempts to realign transnational governance actors with traditional concepts of the state or of civil society. In contrast, a more promising avenue of inquiry seems to involve a study of the evolving actors and norms on the basis of advances made in sociology and anthropology with regard to the evolution of 'social norms' and 'spaces'

${ }^{27}$ Sally Falk Moore, 'Law and Social Change: the semi-autonomous field as an appropriate subject of study' (1973) 7 Law \& Society Review 719-746; John Griffiths, 'What is Legal Pluralism?' (1986) 24 Journal of Legal Pluralism and Unofficial Law 1-55

${ }^{28}$ Robert O. Keohane and Joseph S. Nye, 'Introduction' in Joseph S. Nye and John D. Donahue (eds), Governance in a Globalizing World (Brookings Institution, Washington D.C. 2000)

${ }^{29}$ Compare Niklas Luhmann, 'The World Society as a Social System' (1982) 8 International Journal of General Systems 131-138, with John W. Meyer and others, 'World Society and the Nation-State' (1997) 103 American Journal of Sociology 144-181.

${ }^{30}$ See eg, James Thuo Gathii, 'Third World Approaches to International Economic Governance' in Richard A. Falk, Balakrishnan Rajagopal and Jacqueline Stevens (eds), International Law and the Future (Routledge Cavendish, London \& New York 2008), and Richard Peet, Unholy Trinity. The IMF, World Bank and WTO (2nd ed.) (Zed Books, London, UK 2009). 
of governance and regulation ${ }^{31}$, but also the concept of 'economic governance' developed in the context of the New Institutional Economics' ${ }^{32}$

Against this background, this paper seeks to combine a legal sociological perspective with a legal theoretical one for a critical reconstruction of 'legal pluralism' against the background of the concept of transnational law, with the aim of developing a concept of transnational legal pluralism. It attempts to build bridges between, on the one hand, the long-standing introspection into 'law and its other' that has taken place with reference to political institutions and processes, to the state and a legitimating societal body and, on the other hand, the still less known and less travelled global space. The concept of transnational legal pluralism to be developed in this article goes beyond Philip Jessup's 1956 idea of 'transnational law', through which he sought both to complement and to challenge Public and Private International Law ${ }^{33}$, by bringing together insights from legal sociology and legal theory with research on global justice, ethics and regulatory governance to illustrate (what he coined as) the transnational nature of law and regulation, always pushing against the various claims to legal unity and hierarchy made over time. While for Jessup the reference to 'transnational' served above all to highlight the inability of the existing disciplines of both public and private international law to capture the various border-crossing regulatory interactions between public and private or between private parties, the here proposed concept of transnational legal pluralism is foremost a proposal to conceive of transnational law from a methodological perspective. It is thus no longer concerned with a quest for a legal field, which could embrace and regulate the just described border-crossing nature of hybrid regulatory interaction. Instead, the term transnational is meant here to identify a methodological space in which to make sense of the conditions that shape references to law or non-law in functionally highly differentiated contexts.

\footnotetext{
${ }^{31}$ See in particular Sally Engle Merry, 'New Legal Realism and the Ethnography of Transnational Law' (2006) 31 Law \& Soc Inquiry 975-995; Saskia Sassen, 'The State and Globalization' in Joseph S. Nye and John D. Donahue (eds), Governance in a Globalizing World (Brookings Institution, Washington D.C. 2000); Saskia Sassen, Territory Authority - Rights. From Medieval to Global Assemblages (Princeton University Press, Princeton, NJ/Oxford, UK 2006), and Saskia Sassen, 'The Places and Spaces of the Global: An Expanded Analytic Terrain' in David Held and Anthony McGrew (eds), Globalization Theory Approaches and Controversies (Polity, London 2007). See also Annelise Riles, 'Comparative Law and Socio-Legal Studies' in Mathias Reimann and Reinhard Zimmermann (eds), Oxford Handbook of Comparative Law (Oxford University Press, Oxford/New York 2006).

${ }^{32}$ See only Oliver E. Williamson, 'The Economics of Governance' (2005) 95 American Economic Review 1-18.

${ }^{33}$ Philip C. Jessup, Transnational Law (Storrs Lectures in Jurisprudence at Yale Law School, Yale University Press, New Haven 1956); Wolfgang Friedmann, Louis Henkin and Oliver Lissitzyn (eds), Transnational Law in a Changing Society. Essays in the Honor of Philip C. Jessup (Columbia University Press, New York 1972); Christian Tietje, Alan Brouder and Karsten Nowrot, Philip C. Jessup's Transnational Law Revisited (Essays in Transnational Law No.50/2006) (Essays in Transnational Law No50/2006, Halle); Peer Zumbansen, 'Transnational Law' in Jan Smits (ed) Encyclopedia of Comparative Law (Edward Elgar, 2006)
} 
These contexts -- such as financial markets ${ }^{34}$, online sales contracts ${ }^{35}$ or labour regulations in and around multinational enterprises ${ }^{36}$-- are characterised by a complex amalgamation of 'hard' and 'soft', direct and indirect norms that no longer fit under the semantic umbrella of existing disciplinary fields such as labour law or corporate law. As a result, not only have the scope and content of such fields come under pressure; more importantly, the intersection of different forms of 'regulatory governance' with regard to such contexts must now be assessed through a methodological lens. From this perspective, then, the first insight is into the distinctly interdisciplinary nature of the regulation that marks a particular context. We see here an intricate co-existence, overlap and often competition between legal and, say, economic rules. ${ }^{37}$ The further insight, of crucial importance from a legal theory point of view, is into the status of law in this mixed regulatory landscape, and it is here where a concept of transnational legal pluralism must reach beyond Jessup's identification of a particular exhaustion of existing disciplinary fields to depict border-crossing, hybrid interaction. The central point of the transnational perspective embraced here is that, despite an emerging consensus regarding the co-existence of legal and 'other' forms of regulation, an observation informed above all by the distinction between 'formal' and 'informal' institutions in the context of New Institutional Economics $^{38}$, we are still at a loss as to how to distinguish between a legal and a non-legal form of regulation. As long as the distinction is based on the reference to a particular authority, which alone is entrusted with the production of legal rules - commonly understood to be the state - the distinction will result in an identification of 'formal' institutions with 'law' and the state, while almost every other norm apt to govern or guide human behaviour can only be considered as an 'informal'. What is left outside of this demarcation is the question of 'What is at stake?' in the choice between a legal and an alternative form of regulation.

\footnotetext{
${ }^{34}$ Saskia Sassen, 'The Embeddedness of Electronic Markets: The Case of Global Capital Markets' in Karin Knorr Cetina and Alex Preda (eds), The Sociology of Financial Markets (Oxford University Press, Oxford, UK/New York, NY 2005)

${ }^{35}$ Gralf-Peter Calliess and Peer Zumbansen, Rough Consensus and Running Code: A Theory of Transnational Private Law (Hart Publishing, Oxford, UK 2010) 153-180

${ }^{36}$ Harry Arthurs, 'Corporate Self-Regulation: Political Economy, State Regulation and Reflexive Labour Law' in Brian Bercusson and Cynthia Estlund (eds), Regulating Labour in the Wake of Globalisation (Hart Publishing, Oxford, UK \& Portland, OR 2008)

${ }^{37}$ For an illustration, see Lisa Bernstein, 'Private Commercial Law in the Cotton Industry: Creating Cooperation Through Rules, Norms, and Institutions' (2001) 99 Michigan Law Review 1724-1790, and Gillian K. Hadfield and Eric Talley, 'On Public versus Private Provision of Corporate Law' (2006) $22 \mathrm{~J}$ Law, Econ \& Org 414-441, for an extensive discussion see Calliess and Zumbansen, Rough Consensus, supra, 80, 87-96.
}

${ }^{38}$ See Douglass C. North, 'Institutions' (1991) 5 J Econ Persp 97-112, and Oliver E. Williamson, 'The New Institutional Economics: Taking Stock, Looking Ahead' (2000) 38 Journal of Economic Literature 595-613. 
For lawyers, this remains extremely unsatisfactory, because the distinction can only be sustained in blunt negation of the far-reaching legal pluralist insights into the many forms of legal normative orders. As a result, because lawyers are bound to remain troubled by the economists' demarcation of formal versus informal, an important step towards a more adequate assessment of the regulatory pluralism characterizing the mentioned contexts is to put a central emphasis on how the distinction between law and non-law is in fact made. It is here where lawyers are likely to unfold different set of distinctions than that which has been informing the economist's study of institutions. While the economist is herself pushing ever deeper into the 'institutional diversity' which marks complex regulatory and self-regulatory contexts $^{39}$, the gained insights remain confined to an (admittedly better) understanding of the various rules, norms and behaviour-governing institutions present in such contexts. Meanwhile, the process through which the distinction between the legal and a non-legal character of any such institution is made remains opaque, as long as the distinction is loosely attached to references to state-based or non-state-based norm-making authorities. Against the background of legal pluralist insights into the different forms of legal regulation, based on which formal legal systems were being put to the test in terms of their legitimacy, openness to change and their access to justice ${ }^{40}$, such a narrow interpretation of law cannot stand.

Central to the project of transnational legal pluralism are, thus, the following two methodological premises. The first concerns the inquiry into the elements that inform the distinction between law and non-law in any given regulatory context. Precisely because 'alternatives' to legal regulation have become impressingly self-assured in asserting their interpretive and governing grip on complex constellations ${ }^{41}$, it is even more important to ask whether there is in fact any role left for law and, in particular, for law's operation to introduce the distinction between legal and illegal with regard to a social context. ${ }^{42}$ The role of law, as will be developed in more detail below, remains in facilitating and structuring the space in which trade-offs between legal and non-legal regulations occur. This structuring of law is bound to function with references to the learned contexts and institutional frameworks associated with law in a given place at a given time, which explains a certain preoccupation among contintental

39 Elinor Ostrom, Understanding Institutional Diversity (Princeton University Press, Princeton, NJ 2005); Elinor Ostrom, 'Challenges and growth: the development of the interdisciplinary field of institutional analysis' (2007) 3 Journal of Institutional Economics 239-264

40 David Trubek, 'Toward a Social Theory of Law: An Essay on the Study of Law and Development' (1972) 82 Yale Law Journal 1-50; John Griffiths, 'What is Legal Pluralism?' (1986) 24 Journal of Legal Pluralism and Unofficial Law 1-55; Günter Frankenberg, 'Why Care? - The Trouble with Social Rights' (1996) 17 Cardozo Law Review 1365-1390

${ }^{41}$ For a critical discussion, see only David Charny, 'Illusions of a Spontaneous Order: 'Norms' in Contractual Relationships' (1996) 144 University of Pennsylvania Law Review 1841-1858.

42 Niklas Luhmann, 'Law as a Social System' (1989) 83 Northwestern University Law Review 136-150 
European lawyers with the allegedly central role of the 'state' in the creation and enforcement of legal rules. At the same time, the comparative assessment of the binding or mandatory character of law, even in areas of intense market regulation and self-regulation such as corporate law, already reveals striking differences in the perception of what is and is not necessary in order to achieve an adequate level of ordered conduct. ${ }^{43}$

The second methodological premise concerns the transnational dimension in the legal pluralist analysis, which is proposed here. 'Transnational' demarcates not a territorially defined and demarcated space, across the boundaries of which regulations are seen to be either successful or unsuccessful in governing or prescribing behaviour. Rather, the term depicts the space in which the legal pluralist analysis of legal and non-legal regulation occurs. It makes reference to the space that is left empty between conceptualizations of a legal order from either a 'national' or 'international' perspective. The term transnational is closely connected to the sociological model of the 'world society', a term that radicalizes the idea of functional differentiation and traces communications (in law, economics, religion, politics) primarily with reference to the particular rationalities of such systems. 'Primarily', because any system-theoretical assessment is likely to continue, for some time to come, to incorporate references to the 'context' in which systematic communications occur. From the vantage point of much of Western legal theory, this context is predominantly the state and, more particularly, the nation state. However, from the perspective of transnational legal pluralism, while this context may still be referenced merely to better trace the evolution of a particular system over time, it does not in itself explain or capture a particular system. In other words, the 'transnational' element in transnational legal pluralism seeks to capture this transition process in legal theory from a state-based depiction and interpretation of legal norms to a conceptualization of legal norm creation that unfolds according to principles of functional differentiation.

The remainder of the paper proceeds as follows: The next section (2.) revisits the legal pluralist insights into what is a paradoxical relation between law and non-law. Against this background, the paper traces the emergence of border-crossing regulatory regimes as a challenge to stateoriented legal reasoning (3.) before illustrating the parallels between the impasses of legal theorising about 'global' or 'transnational' governance with those that marked the evolution ofthe study of law in the nation- state. Section 4 revisits the frequently asked question whether globalisation marks the end of law: attempting a negative answer ('law is dead - long live law!'), this section proposes to read the emergence of 'transnational law' not as the advent of a 'new' field - similar to the way that, say, environmental law or internet law were once considered novel fields only relatively recently. Instead, as pointed out above, the central assumption is

\footnotetext{
43 Compare Robert C. Clark, Corporate Law (Brown \& Little, Boston 1986) with Herbert Wiedemann, Gesellschaftsrecht, Bd. I (C.H.Beck, München 1980); for a brillant discussion of the different approaches, see Friedrich Kübler, 'The Impact of Equity Markets on Business Organization: Some Comparative Observations Regarding Differences in the Evolution of Corporate Structures' (2001) 2 European Business Organization Law Review [EBOR] 669-683 and Friedrich Kübler, 'A Shifting Paradigm of European Company Law?' (2005) 11 Colum J Eur L 219-240
} 
that transnational law constitutes a methodological perspective, or paradigm shift in legal theory - an attempt to bridge the experience of legal pluralism in the nation state with that of the functionally differentiated world society, that Jessup still sought to capture with reference to an emerging transnational space. Section 5 pursues this argument and applies it to the initial paradox between law and non-law. Transnational law can now be understood as a lens through which to perceive the argumentative parallels between the impasses, roadblocks and 'impossibilities' of law that recur both 'inside' and 'outside' of the nation state. As the borders of the state are reconstructed as historically contingent reference points for the evolution of legal reasoning, transnational law becomes the legal theoretical reconstruction of law/non-law in the world society. The concluding section (6) sets out the framework of transnational legal pluralism.

\section{LAW AND ITS OTHER}

Today, many regulatory areas can only be understood as instantiations of global norm-creation. Supply chains that tie regional and global markets together ${ }^{44}$, commercial arbitration ${ }^{45}$, food safety and food quality standardisation regimes ${ }^{46}$, internet governance ${ }^{47}$, but also

44 Francis Snyder, 'Global Economic Networks and Global Legal Pluralism' in George A. Bermann, Matthias Herdegen and Peter L. Lindseth (eds), Transatlantic Regulatory Co-operation (Oxford University Press, Oxford/New York 2000); Francis Snyder, 'Economic Globalisation and the Law in the 21st Century' in Austin Sarat (ed) The Blackwell Companion to Law and Society (Blackwell, New York \& Oxford 2004).

${ }^{45}$ Clive M. Schmitthoff, 'The New Sources of the Law of International Trade' (1963) 15 International Social Science Journal 259-264; Filip De Ly, 'Lex Mercatoria (New Law Merchant): Globalisation and International Self-Regulation' in Volkmar Gessner, Richard P. Appelbaum and William F. Felstiner (eds), Rules and Networks The Legal Culture of Global Business Transactions (Hart Publishing, Oxford/Portland, OR 2001).

${ }^{46}$ Patrycja Dabrowska, 'Risk, Precaution and the Internal Market: Who Won the Day in the Recent Monsanto Judgement of ECJ on GM foods' (2004) 5 German Law Journal 151-166; Dayna Nadine Scott, 'Nature/Culture Clash: The Transnational Trade in GMOs' (2005) Global Law Working Paper Series http://www.nyulawglobal.org/GLWP_0605.htm; Antonia Eliason, 'Science versus Law in WTO Jurisprudence: The (Mis)Interpretation of the Scientific Process and the (In)sufficiency of Scientific Evidence in Ec-Biotech' (2009) 41 New York University Journal of International Law \& Politics 341-406.

${ }^{47}$ David D. Clark, 'A Cloudy Crystal Ball: Visions of the Future' (1992) Plenary Presentation at 24th meeting of the Internet Engineering Task Force, Cambridge, Massachusetts, $13-17 \quad$ July 1992 (http://ietf20.isoc.org/videos/future_ietf_92.pdf); Christoph Engel, 'The Role of Law in the Governance of the Internet' (2002) <http://www.mpp-rdg.mpg.de/pdf_dat/2002_13.pdf> accessed ; Jack Goldsmith, 'The Internet, Conflicts of Regulation and International Harmonisation' in Christoph Engel and Kenneth H. Keller (eds), Governance of Global Networks in the Light of Differing Local Values (Nomos, Baden-Baden 2000); Jochen von Bernstorff, 'The Structural Limitations of Network Governance: ICANN as a Case in Point' in Gunther Teubner, Christian Joerges and Inger-Johanne Sand (eds), Transnational Governance and Constitutionalism (Hart Publishing, Oxford, UK \& Portland, OR 2004). 
environmental protection ${ }^{48}$ crime $^{49}$ and terrorism ${ }^{50}$ are key examples of fast expanding spaces of individual, organizational and regulatory activity that evolve with little regard for jurisdictional boundaries but, instead, appear to develop according to functional imperatives. Similarly, fields such as corporate, insolvency and even labour law that had long been understood as embedded in historically evolved political and regulatory economies ${ }^{51}$, today display a distinctly de-nationalised character ${ }^{52}$, which we should approach from the distinct methodological perspective indicated above. Constituted through a complex overlapping of different national, international, public and private norm-creation processes, these fields underscore the conundrical nature of a proliferating and expanding global regulatory space: in response, state-based responses that draw on architectures of normative hierarchy, separation

48 Jutta Brunnée, 'Of Sense and Sensibility: Reflections on International Liability Regimes as Tools for Environmental Protection' (2004) 53 International and Comparative Law Quarterly 351-367; Oren Perez, Ecological Sensitivity and Global Legal Pluralism. Rethinking the Trade and Environment Conflict (International Studies in Private Law Theory, Hart Publishing, Oxford/Portland, OR 2004); Russell Miller and Rebecca Bratspies (eds), Transboundary Harm: Lessons from the Trail Smelter Arbitration (Transboundary Harm: Lessons from the Trail Smelter Arbitration, Cambridge University Press, Cambridge 2006); Andrew P. Morriss and Roger E. Meiners, 'Borders and the Environment' (2009) 39 Environmental Law 141-192.

49 Tomer Broude and Doron Teichman, 'Outsourcing and Insourcing Crime: The Political Economy of Globalized Criminal Activity' (2009) 62 Vanderbilt Law Review 795-848.

${ }^{50}$ Ulrich Beck, 'Living in the world risk society' (2006) 35 Economy and Society 329-345; Ulrich Beck, 'Critical Theory of World Risk Society: A Cosmopolitan Vision' (2009) 16 Constellations 3-22; Ulrich Beck, World at Risk [orig. German "Weltrisikogesellschaft" (Frankfurt: Suhrkamp); Ciaran Cronin, transl.] (polity, Cambridge, UK \& Malden, MA (U.S.A.) 2009).

${ }^{51}$ See, eg: Sigurt Vitols, 'Varieties of Corporate Governance: Comparing Germany and the UK' in Peter A. Hall and David Soskice (eds), Varieties of Capitalism The Institutional Foundations of Comparative Advantage (Oxford University Press, Oxford/New York 2001), and Klaus J. Hopt, 'Common Principles of Corporate Governance in Europe?' in Joseph A. McCahery and others (eds), Corporate Governance Regimes Convergence and Diversity (Oxford University Press, Oxford/New York 2002).

52 Harry Arthurs and Claire Mummé, 'From Governance to Political Economy: Insights from a Study of Relations between Corporations and Workers' (2007) 45 Osgoode Hall Law Journal 439-470; Jennifer Gordon, 'Transnational Labor Citizenship' (2007) 80 Southern California Law Review 503-587; Peer Zumbansen, 'New Governance' in European Corporate Governance Regulation as Transnational Legal Pluralism' (2009) 15 European Law Journal 246276 [available at http://ssrn.com/abstract=1128145]; Horst Eidenmüller, 'Recht als Produkt' (2009) 64 Juristenzeitung [JZ] 641-653. 
of powers and unity of law ${ }^{53}$ are likely to fall short of grasping the nature of the evolving transnational normative order. ${ }^{54}$

In their search for appropriate labels, concepts and instruments for this regulatory space lawyers have long been forming alliances with scholars in a wide range of social sciences including sociology, political science, economics or geography. ${ }^{55}$ Such interdisciplinary collaboration in practice and methodology is anything but new to law and legal theory: building as it does on early beginnings made by social scientists that emphasised the importance of social facts and increasingly incorporated empirical findings ${ }^{56}$, the study of law has for the longest time been carried out in close proximity and in the constant shadow of social studies. ${ }^{57}$ The legal sociological projects at the end of the $19^{\text {th }}$ and the beginning of the $20^{\text {th }}$ century ${ }^{58}$ can

${ }^{53}$ For an inspiring discussion, see Klaus Günther, 'Legal Pluralism or uniform concept of law?' (2008) 5 no foundations [NoFo] 5-21; Florian F. Hoffmann, 'In Quite a State: Trials and Tribulations of an Old Concept in New Times' in Russell A. Miller and Rebecca Bratspies (eds), Progress in International Law (Martin Nijhoff, The Hague 2008); William Twining, Globalisation and Legal Theory (Northwestern University Press, Evanston, IL 2000).

54 Oren Perez, 'Normative Creativity and Global Legal Pluralism: Reflections on the Democratic Critique of Transnational Law' (2003) 10 Indiana Journal of Global Legal Studies 25-64; Peer Zumbansen, 'Transnational Law' in Jan Smits (ed) Encyclopedia of Comparative Law (Edward Elgar, 2006); T. Alexander Aleinikoff, 'Transnational Spaces: Norms and Legitimacy' (2008) 33 Yale Journal of International Law 479-490; Alec Stone Sweet, 'Constitutionalism, Legal Pluralism, and International Regimes' (2009) 16 Indiana Journal of Global Legal Studies 621-645; Craig M. Scott, "Transnational Law' as Proto-Concept: Three Conceptions' (2009) 10 German Law Journal 859-876.

55 Rebecca Bratspies, 'Regulatory Trust' (2009) 51 Arizona Law Review 575-631; see the contributions to Edward Balleisen and David Moss (eds), Government and Markets: Toward a New Theory of Regulation (Cambridge University Press, Cambridge, UK 2009).

${ }^{56}$ Adam Ferguson, An Essay on the History of Civil Society [1767] (Cambridge University Press, Cambridge 1995); Emile Durkheim, The Division of Labor in Society [1893; transl. by W.D. Halls] (Free Press, New York 1984).

${ }^{57}$ Henry Sumner Maine, Ancient Law. Its connection with the early history of society, and its relation to modern ideas (John Murray, London 1861); Ferdinand Tönnies, Community and Society [Gemeinschaft und Gesellschaft, orig. German 1887, transl. Ch. P. Loomis, Michigan State University Press, 1957] (Transaction Publishers, New Brunswick, NJ 1988); Max Weber, On Law in Economy and Society (transl. from the German Wirtschaft und Gesellschaft, 2nd ed., 1925, by E.Shils and M.Rheinstein, edited/annotated by M.Rheinstein) (Simon Schuster, New York 1967).

${ }^{58}$ Emile Durkheim, The Division of Labor in Society [1893; transl. by W.D. Halls] (Free Press, New York 1984); Max Weber, On Law in Economy and Society (transl. from the German Wirtschaft und Gesellschaft, 2nd ed., 1925, by E.Shils and M.Rheinstein, edited/annotated by M.Rheinstein) (Simon Schuster, New York 1967); Eugen Ehrlich, Fundamental Principles of the Sociology of Law (orig. published in German as Grundlegung der Soziologie des Rechts, 1913) (Russell \& Russell, New York 1962); Georges Gurvitch, Sociology of Law (orig. published in French as Problèmes de la sociologie du droit) (Routledge and Kegan Paul, London 1947). 
today be seen as eminent precursors for a presently further intensifying study of the institutional foundations of legal systems in a constellation marked by the erosion of boundaries between domestic legal orders and the continuing contestation of the normativeconceptual foundations of the Rule of Law as well as the welfare state and its ambiguous aftermath. ${ }^{59}$ The Legal Realist attack on formalism ${ }^{60}$, the post-War natural law/legal positivism debate $^{61}$, the emergence of a particular strand of legal pluralism in the wake of postcolonialism $^{62}$, the rise of 'law \& society' - both from the left ${ }^{63}$ and from the right ${ }^{64}$ - as well as the critique of juridification ${ }^{65}$ have since given way to a cacophonic contestation of the merits and limits of 'law's knowledge', its evolving nature and role. ${ }^{66}$

59 David Trubek, 'Toward a Social Theory of Law: An Essay on the Study of Law and Development' (1972) 82 Yale Law Journal 1-50; Gunther Teubner (ed), Dilemmas of Law in the Welfare State (Walter de Gruyter, Berlin/New York 1986).

${ }^{60}$ See, eg: Oliver Wendell Jr. Holmes, 'The Path of the Law' (1897) 10 Harvard Law Review 457, and Felix Cohen, 'Transcendental Nonsense and the Functional Approach' (1935) 35 Columbia Law Review 809-849; Duncan Kennedy, The Rise and Fall of Classical Legal Thought (1975) (Beard Books, Cambridge, MA 2006); a very worthwhile discussion and analysis with a stunning treatment of the literature is provided by Neil Duxbury, Patterns of American Jurisprudence (Oxford University Press, Oxford 1995).

${ }^{61}$ H.L.A. Hart, 'Positivism and the Separation of Law and Morals' (1958) 71 Harvard Law Review 593; Lon Fuller, 'Fidelity to Law - A Reply to Professor Hart' (1958) 71 Harvard Law Review 629-672; H.L.A. Hart, 'American Jurisprudence Through English Eyes: The Nightmare and the Noble Dream' (1977) 11 Georgia Law Review 969-989; Stanley L. Paulson, 'On the Background and Significance of Gustav Radbruch's Post-War Papers' (2006) 26 Oxford Journal of Legal Studies 17-40.

62 Sally Falk Moore, 'Law and Social Change: the semi-autonomous field as an appropriate subject of study' (1973) 7 Law \& Society Review 719-746; Boaventura de Sousa Santos, 'Law: A Map of Misreading. Toward a Postmodern Conception of Law' (1987) 14 Journal of Law \& Society 279; Sally Engle Merry, 'Legal Pluralism' (1988) 22 Law \& Society Review 869-901.

63 David Trubek, 'Toward a Social Theory of Law: An Essay on the Study of Law and Development' (1972) 82 Yale Law Journal 1-50; Marc Galanter, 'Why the 'Haves' Come Out Ahead: Speculations on the Limits of Legal Change' (1974) 9 Law \& Society Rev 95-160.

${ }^{64}$ Guido Calabresi, The Cost of Accidents. A Legal and Economic Analysis (Yale University Press, New Haven 1970); Richard A. Posner, Economic Analysis of Law (Little Brown, Boston 1973).

${ }^{65}$ Philippe Nonet and Philip Selznick, Law and Society in Transition. Toward Responsive Law (Octagon Books, New York 1978); Gunther Teubner, 'Juridification - Concepts, Aspects, Limits, Solutions' in Gunther Teubner (ed) Juridification of Social Spheres (Walter de Gruyter, Berlin/New York 1987).

${ }^{66}$ Duncan Kennedy, 'Three Globalizations of Law and Legal Thought: 1850-2000' in David Trubek and Alvaro Santos (eds), The New Law and Economic Development (Cambridge University Press, Cambridge 2006); Boaventura de Sousa Santos, Toward a New Legal Common Sense: Law, Globalization, and Emancipation (Law in Context, Cambridge University Press, Cambridge 2002). 
Seen in this light, the search for the 'nature of law' has always been carried out with the pretentious assumption that it is or must be different, that law is - or, in the end can be different from religion, morality, and economics. ${ }^{67}$ But the short twentieth century has left this idea of law battered and torn, scarred and violated. ${ }^{68}$ Any attempt, then, to resurrect this assumption must either be perceived as naïve or as incredulously courageous. Law as a means of oppression, of corruption and domination, or law as a promise of hope, as an instrument of liberation and emancipation? Its schizophrenic character is owed to its paradoxical foundation $^{69}$, the impossibility of its legitimate creation out of a void ${ }^{70}$, out of one or more acts of violence. ${ }^{71}$ Historically, as law differentiates and emancipates itself from politics, economics, religion, not in order to 'rise above' but, rather, to immerse and embrace and to juridify society in its inexhaustible complexity ${ }^{72}$, it threatens either to suffer the fate of Icarus or to evaporate into thin air. Its immodest, impossible claim must be to be outside of society (politics, economics, religion), but at the same time to be (the law of) society. ${ }^{73}$ That law can only be understood in relation to that which it wishes to distinguish and offset itself from, ought to be the starting point for understanding the nature of law, not an earth-shattering revelation after a seminar in deconstruction. Law's other is, thus, deeply inherent to any program of law and in law's lurking denial, ridiculisation and (self-) destruction.

${ }^{67}$ See already Oliver Wendell Jr. Holmes, 'The Path of the Law' (1897) 10 Harvard Law Review 457.

${ }^{68}$ Reinhart Koselleck, 'Geschichte, Recht und Gerechtigkeit (1986)' (2000) Frankfurt: Suhrkamp ders, Zeitschichten Studien zur Historik 336-358; Upendra Baxi, The Death of Human Rights, 2nd ed. (Oxford University Press, Oxford and New York 2005).

${ }^{69}$ Gunther Teubner, 'How the Law Thinks: Toward a Constructivist Epistemology of Law' (1989) 23 Law \& Society Review 727-758; Gunther Teubner, 'Dealing With Paradoxes: Derrida, Luhmann, Wiethölter' in Oren Perez and Gunther Teubner (eds), Paradoxes and Inconsistencies in Law (Hart Publishing, Portland, OR/Oxford, UK 2006)

${ }^{70}$ Carl Schmitt, Political Theology: Four Chapters on the concept of sovereignty [1922] (transl. George Schwab) (Studies in Contemporary German Social Thought, The MIT Press, Cambridge, MA 1986)

${ }^{71}$ Walter Benjamin, 'The Critique of Violence [Zur Kritik der Gewalt, Edmund Jephcott trans.]' in Peter Dementz (ed) Reflections: Essays, Aphorisms, Autobiographical Writings (Schocken, New York City 1978); Jacques Derrida, 'Force of law' (1990) 11 Cardozo Law Review 919-1045; for an excellent discussion and homage, see Petra Gehring, 'Force and "Mystical Foundation" of Law: How Jacques Derrida Addresses Legal Discourse' (2005) 6 German Law Journal 151-169, and the contributions to the same issue (edited by Cornelia Vismann \& Florian Hoffmann).

72 Niklas Luhmann, Ausdifferenzierung des Rechts. Beiträge zur Rechtssoziologie und Rechtstheorie (Suhrkamp, Frankfurt 1981), 35: "Das Rechtsystem einer Gesellschaft besteht aus allen sozialen Kommunikationen, die mit Bezugnahme auf das Recht formuliert werden." [The legal system of society consists of all social communications that are formulated with reference to law, PZ TRANSL.]

${ }^{73}$ See Rudolf Wiethölter, 'Just-ifications of a Law of Society' in Oren Perez and Gunther Teubner (eds), Paradoxes and Inconsistencies in the Law (Hart Publishing, Oxford/Portland 2006); Marc Amstutz, 'The Letter of the Law: Legal Reasoning in a Societal Perspective' (2009) 10 German Law Journal 361-382, 362. 
Table 1: Definitions of Law

\begin{tabular}{|l|l|}
\hline $\mathbf{1}$ & Law as institutionalised system of rule enforcement \\
\hline $\mathbf{2}$ & Law as a means of stabilizing expectations \\
\hline $\mathbf{3}$ & Law as means of oppression \\
\hline $\mathbf{4}$ & Law as hope \\
\hline $\mathbf{5}$ & Law as parasite - without method, heart, or soul ...? \\
\hline
\end{tabular}

The difficulty in understanding law has to be seen against the background of a blurring of boundaries between 'law' and 'society'. ${ }^{74}$ As pointed out by Roger Cotterrell, '[I]aw constitutes society in so far as it is, itself, an aspect of society, a framework and an expression of understandings that enable society to exist. A sociological perspective on legal ideas is necessary to recognise and analyse the intellectual and moral power of law in this respect. ${ }^{75}$ Understanding law, then, as a 'social phenomenon' ${ }^{76}$, Cotterrell observes that the distinction between law and society does indeed blur: the internal/external distinction is 'replaced by a conception of partial, relatively narrow or specialised participant perspectives on (and in) law, confronting and being confronted by, penetrating, illuminating, and being penetrated and illuminated by, broader, more inclusive perspectives on (and in) law as a social phenomenon. ${ }^{77}$ He rightly posits that the '[s]ociological interpretation of legal ideas is not a particular, specialized way of approaching law, merely co-existing with other kinds of understanding. Sociology of law in this particular context is a transdisciplinary enterprise and aspiration to broaden understanding of law as a social phenomenon. ${ }^{78}$ Such a perspective on law must be understood as an attempt to respond to law's own lack of methodology: 'Law does not have a 'methodology of its own' and borrows methodologies from any discipline that can supply

\footnotetext{
74 Roger Cotterrell, 'Why Must Legal Ideas Be Interpreted Sociologically?' (1998) 25 Journal of Law \& Society 171192, 176.

${ }^{75}$ Cotterrell, 1998, 182.

${ }^{76}$ Cotterrell, 1998, 187: 'Sociological interpretation of legal ideas is not a particular, specialized way of approaching law, merely co-existing with other kinds of understanding. Sociology of law in this particular context is a transdisciplinary enterprise and aspiration to broaden understanding of law as a social phenomenon.'

${ }^{77}$ Cotterrell, 1998, 188.

${ }^{78}$ Cotterell, 1998, 187.
} 
them. $^{, 79}$ He concludes that a sociological reflection on legal ideas would be to reflect 'methodologically law's own fragmentary varied methodological characteristics' ${ }^{80}$

\section{The Transnationalisation OF Legal GovernanCE}

\section{A. LAW'S UTOPIA}

As the shifting of our analytical focus beyond the boundaries of the nation state has been providing the stage for the study of law in the recent past ${ }^{81}$, the here proposed framework of transnational legal pluralism ${ }^{82}$ seeks to capture the methodological challenge arising for law and social theory to make sense of the emerging normative order of the world society. In situating this concept in dialogue with theoretical approaches regarding 'transnational law ${ }^{83}$, 'transnational commercial law' ${ }^{84}$, 'global law' ${ }^{85}$, 'law and globalisation' ${ }^{86}$, 'transnational

${ }^{79}$ Cotterrell, 1998, 178, with reference to Jack M. Balkin, 'Interdisciplinarity as Colonization' (1996) 53 Washington \& Lee Law Review 949-970.

${ }^{80}$ Cotterrell, 1998, 189.

81 James C. Scott, Seeing like a State. How Certain Schemes to Improve the Human Condition Have Failed (Yale University Press, New Haven/London 1998); Niklas Luhmann, 'Metamorphosen des Staates' (1995) in: Luhmann, Gesellschaftsstruktur und Semantik Studien zur Wissenssoziologie der modernen Gesellschaft 101-137.

${ }^{82}$ Zumbansen, New Governance, above; Gralf-Peter Calliess and Peer Zumbansen, Rough Consensus and Running Code: A Theory of Transnational Private Law (Hart Publishing, Oxford, UK 2010) (2010), above, ch. 2.

${ }^{83}$ Philip C. Jessup, Transnational Law (Storrs Lectures in Jurisprudence at Yale Law School, Yale University Press, New Haven 1956); Craig M. Scott, "Transnational Law' as Proto-Concept: Three Conceptions' (2009) 10 German Law Journal 859-876.

${ }^{84}$ Roy Goode, 'Usage and Its Reception in Transnational Commercial Law' (1997) 46 International and Comparative Law Quarterly 1-36; Ross Cranston, 'Theorizing Transnational Commercial Law' (2007) 42 Texas International Law Journal 597-617.

${ }^{85}$ Gunther Teubner (ed), Global Law Without A State (Ashgate, Aldershot 1997).

86 Paul Schiff Berman, 'From International Law to Law and Globalization' (2005) 43 Columbia Journal of Transnational Law 485-556; Mathias Reimann, 'From the Law of Nations to Transnational Law: Why We Need a New Basic Course for the International Curriculum' (2004) 22 Penn State International Law Review 397-415; Frédéric Mégret, 'Globalization and International Law' (2009) Max Planck Encyclopedia of International Law http://ssrn.com/abstract=1200782; Peer Zumbansen, 'Globalization and the Law: Deciphering the Message of Transnational Human Rights Litigation' (2004) 5 German Law Journal 1499-1520; Craig Scott, 'A Core Curriculum for the Transnational Legal Education of JD and LLB Students: Surveying the Approach of the International, 
spaces' $^{87}$ and 'communities' ${ }^{88}$, 'global legal pluralism' ${ }^{89}$, 'hard versus soft law' ${ }^{\prime 90}$, 'law and social norms ${ }^{\prime 91}$ or, "law as product' ${ }^{92}$, the conceptual boundaries of the here pursued approach are constantly relativised and challenged by these parallel endeavours.

Comparative and Transnational Law Program at Osgoode Hall Law School' (2005) 23 Penn State International Law Review 757-773.

${ }^{87}$ Richard Ford, 'Law's Territory (A History of Jurisdiction)' (1999) 97 Michigan Law Review 843; Saskia Sassen, Territory - Authority - Rights. From Medieval to Global Assemblages (Princeton University Press, Princeton, NJ/Oxford, UK 2006); Saskia Sassen, 'The Places and Spaces of the Global: An Expanded Analytic Terrain' in David Held and Anthony McGrew (eds), Globalization Theory Approaches and Controversies (Polity, London 2007); Shaunnagh Dorsett and Shaun McVeigh, 'Questions of jurisdiction' in Shaun McVeigh (ed) Jurisprudence of Jurisdiction (Routledge-Cavendish, Oxford \& New York 2007); T. Alexander Aleinikoff, 'Transnational Spaces: Norms and Legitimacy' (2008) 33 Yale Journal of International Law 479-490.

${ }^{88}$ Roger Cotterrell, 'A Legal Concept of Community' (1997) 12 Canadian Journal of Law \& Society 75-91; Roger Cotterrell, 'Transnational Communities and the Concept of Law' (2008) 21 Ratio Juris 1-18.

89 Paul Schiff Berman, 'Global Legal Pluralism' (2007) 80 Southern California Law Review 1155-1237; Ralf Michaels, 'Global Legal Pluralism' (2009) Duke Public Law \& Legal Theory Research Paper No 259 http://papers.ssrn.com/sol3/papers.cfm?abstract_id=1430395.

${ }^{90}$ Kenneth W. Abbott and Duncan Snidal, 'Hard and Soft Law in International Governance' (2000) 54 International Organization 421-456; Christine Chinkin, 'The Challenge of Soft Law: Development and Change in International Law' (1989) 38 International and Comparative Law Quarterly 850-866; see further the contributions to John J. Kirton and Michael J. Trebilcock (eds), Hard Choices, Soft Law. Voluntary Standards in Global Trade, Environment and Social Governance (Ashgate, Aldershot 2004); see also the excellent discussion in Larry Catá Backer, 'The OECD Guidelines for Multinational Corporations: Using Soft Law to Operationalize a Transnational System of Corporate Governance' (2009) Law at the End of the Day (Blog) http://lcbackerblog.blogspot.com/2009/2003/oecdguidelines-for-multinational.html, and Gregory Shaffer and Mark A. Pollack, 'Hard vs. Soft Law: Alternatives, Complements and Antagonists in International Governance' (2009) University of Minnesota Legal Studies Research Paper No 09-23 http://ssrn.com/abstract=1426123.

${ }^{91}$ See Eric A. Posner, Law and Social Norms (Harvard University Press, Cambridge, MA \& London, UK 2000); John N. Drobak (ed), Norms and the Law (Cambridge University Press, Cambridge 2006); for a critical perspective see the author of 'Order without Law', Robert C. Ellickson, 'Law and Economics Discovers Social Norms' (1998) 27 Journal of Legal Studies 537-565; see also the magnificent analysis of the inherent depoliticizing effects of the antiregulatory efficiency claim advanced by norm proponents, by David Charny, 'Illusions of a Spontaneous Order: 'Norms' in Contractual Relationships' (1996) 144 University of Pennsylvania Law Review 1841-1858, one of the many outstanding papers in the excellent Symposium Issue on 'Law, Economics, and Norms', published in 144 University of Pennsylvania Law Review 1643-2339 (1996); with regard to the 'norms vs regulation' conflict for example in the current debate over a Common Frame of Reference for European Private Law, see, on the one hand: Jan Smits, 'European Private Law: a Plea for a Spontaneous Legal Order' in Deidre Curtin and others (eds), European Integration and Law (Intersentia, Antwerp \& Oxford 2006), and, on the other: Martijn W. Hesselink, 'A spontaneous order for Europe? Why Hayek's libertarianism is not the right way forward for European private law' (2008) Centre for the Study of European Contract Law, Working Paper Series No 2008/07 http://ssrn.com/abstract=1270566. 
Importantly, this multi-trajectory evolution of legal theory can be studied as a process of law's transnationalisation. Despite its prima facie appearance as being relevant exclusively within the nation state's framework of legal ordering, the just alluded-to scholarly projects in legal sociology and legal theory as well as in anthropology and philosophy of law are reflective of the changing environment of legal systems. This transformation is foremost perceived as one of eroding boundaries, boundaries between form and substance ${ }^{93}$ or between public and private ${ }^{94}$ ('states' and 'markets' ${ }^{\text {'95 }}$ ), but is at its core concerned with the contestation, deconstruction and relativisation of the boundaries between law and non-law. ${ }^{96}$ At the height of the regulatory state with its climactical belief in juridification and in law as social engineering ${ }^{97}$, law stares into the abyss of its own demise and potential irrelevance, and it is from this vantage point that law must be rethought and reasserted as social science, as one among other conceptual approaches to the study of the regulation of modern societies.

92 Roberta Romano, 'Law as Product: Some Pieces of the Incorporation Puzzle' (1985) 1 Journal of Law, Economics and Organizations 225-283; Erin A. O'Hara and Larry E. Ribstein, The Law Market (Oxford University Press, Oxford, UK 2009); Gralf-Peter Calliess and Hermann B. Hoffmann, 'Judicial Services for Global Commerce - Made in Germany?' (2009) 10 German Law Journal 115-123; Gralf-Peter Calliess and Hermann B. Hoffmann, 'Effektive Justizdienstleistungen für den globalen Handel' (2009) 42 Zeitschrift für Rechtspolitik 1-4; Horst Eidenmüller, 'Recht als Produkt' (2009) 64 Juristenzeitung [JZ] 641-653.

93 Duncan Kennedy, 'Form and Substance in Private Law Adjudication' (1976) 89 Harvard Law Review 1685-1778; Duncan Kennedy, 'From the Will Theory to the Principle of Private Autonomy: Lon Fuller's 'Consideration and Form" (2000) 100 Columbia Law Review 94-175.

94 Morton J. Horwitz, The Transformation of American Law 1870-1960 (Oxford University Press, Oxford/New York 1992); Carol Harlow, '"Public" and "Private" Law: Definition without Distinction' (1980) 43 Modern Law Review 241-265.

95 Robert L. Hale, 'Coercion and Distribution in a Supposedly Non-Coercive State' (1923) 38 Political Science Quarterly 470-494; Frances E. Olsen, 'The Family and the Market: A Study of Ideology and Legal Reform' (1983) 96 Harvard Law Review 1497-1578; for a historical discussion: Viktor Vanberg, Markt und Organisation. Individualistische Sozialtheorie und das Problem korporativen Handelns (Mohr Siebeck, Tübingen 1982).

${ }^{96}$ Gunther Teubner, 'The Two Faces of Janus: Rethinking Legal Pluralism' (1992) 13 Cardozo Law Review $1443-$ 1462; Gunther Teubner, 'The King's Many Bodies: The Self-Deconstruction of Law's Hierarchy' (1997) 31 Law \& Society Review 763-787; Boaventura de Sousa Santos, Toward a New Legal Common Sense: Law, Globalization, and Emancipation (Law in Context, Cambridge University Press, Cambridge 2002).

${ }^{97}$ For a discussion of the U.S. development, see Orly Lobel, 'The Renew Deal: The Fall of Regulation and the Rise of Governance in Contemporary Legal Thought' (2004) 89 Minnesota Law Review 342-469; for Germany, see Gunther Teubner, 'Juridification - Concepts, Aspects, Limits, Solutions' in Gunther Teubner (ed) Juridification of Social Spheres (Walter de Gruyter, Berlin/New York 1987). 
Only against this background is it understandable that we are bound to engage in studies of historical forms of legal/non-legal regulation in an ironic/paradoxical sense of law. In other words, references to 'legal' regulation are used in an aspiringly 'water tight' sense in order to demarcate one form of regulation from an alternative form of, say, economic regulation. At the same time, the reference to 'legal' regulation is of course based on the premise that its legal character can only be thought of as paradoxical, as a rejection of something opposite that needs to remain present in order for the other part to make any sense. The paradoxical coexistence of legal and non-legal, then, captures the above-described potentials of law (as oppressor or emancipator), something that history most often records in alternations. Craig Scott has likened the conceptual analysis (concerning the term 'transnational law') to an 'ironic interactive space between keeping faith and breaking faith. Often enough, this will involve digging into a mixture of inchoateness and inconsistencies in the practice or tradition and coming to grips with the epistemological pluralism of the field. ${ }^{98}$

In the concert of different approaches to the regulation of modern society, those fields that seem to escape a clear association with either or regulatory approach, - such as lex mercatoria - begin to play a crucial role in the contemporary assessment of law's role in society, precisely because they challenge our understandings of the nature of legal regulation in fundamental ways. ${ }^{99}$ Well beyond the issue-concerned analysis of the role and place of lex mercatoria in the still evolving field of transnational commercial law ${ }^{100}$, it became and to a certain degree remains $^{101}$ a case in point of a larger critical and legal-sociological inquiry into the possibilities and forms of, as well as into, the scope of legal regulation. Over the last two decades then, the discussion of lex mercatoria, of its historical origins, its nature and scope has always also been an attempt to address the challenge of law by its 'other', by that which might either never

${ }^{98}$ Craig M. Scott, 'Transnational Law' as Proto-Concept: Three Conceptions' (2009) 10 German Law Journal 859876,863 . But see the caveat, id., at 864: "We are, I believe, still in a search of transnational law, including the very concept of 'transnational law', and not yet at the stage of fattening it out (as concept) into a debate over competing conceptions of the best accounts of a consensus abstraction."

${ }^{99}$ Colin Scott, 'Regulating private legislation' in Fabrizio Cafaggi and Horatia Muir-Watt (eds), Making European Law Governance Design (Edward Elgar, Cheltenham, UK 2008), 254: 'The development and application of binding rules have never been the sole preserve of governments.' See also Christiana Ochoa, 'The Relationship of Participatory Democracy to Participatory Law Formation' (2008) 15 Indiana Journal of Global Legal Studies 5-18, 13 '...any dichotomy which sets state-made law and democracy on one side and private law formation and democratic deficits on the other is going to be overly simple.'

100 This section draws, in part, from Gralf-Peter Calliess and Peer Zumbansen, Rough Consensus and Running Code: A Theory of Transnational Private Law (Hart Publishing, Oxford, UK 2010), Chapter 2.

${ }^{101}$ Alex Stone Sweet, 'The new Lex Mercatoria and transnational governance' (2006) 13 Journal of European Public Policy 627-646; Ralf Michaels, 'The True New Lex Mercatoria: Law Beyond the State' (2007) 14 Indiana Journal of Global Legal Studies 447-468. 
become 'law' or is (for various reasons) not yet recognised as law, most likely because lex mercatoria is presented as resulting from private norm-creation and administration and which the legal order observes as an exception or, a threat. ${ }^{102}$ Against the background of the fast intensifying interdisciplinary theoretisations of comparative law and legal pluralism ${ }^{103}$, the lex mercatoria debate must, too, foremost be understood as a methodological challenge asking us to reflect on the possibility-but also the politics - of 'law', which can be but need not to be state-originating, which can be but need not to be privately created or which in fact results from a complex interaction between official and unofficial norm-creation. It is here where the real challenge of lex mercatoria as example for the evolution of an 'autonomous' transnational legal regime ${ }^{104}$ becomes most obvious. Lex mercatoria offers a good insight into the complexity of the concept of transnational law, precisely because of its multi-layered and hybrid nature, in particular as regards the interpenetration of public and private models of norm creation and norm enforcement in this area.

In the absence of world government, attempts to demarcate a legal system adequate to the 'post-national constellation' ${ }^{105}$ feature, above all, a deep-running anxiety in the face of a perceived lack of unity, coherence and institutional and normative hierarchy. ${ }^{106}$ The procedural and substantive architectures of fast-emerging global regulatory regimes ${ }^{107}$ raise questions that

${ }^{102}$ For a powerful illustration of the two sides of such threats, see only J.M. Coetzee, Waiting for the Barbarians (1982).

${ }^{103}$ Annelise Riles, 'Comparative Law and Socio-Legal Studies' in Mathias Reimann and Reinhard Zimmermann (eds), Oxford Handbook of Comparative Law (Oxford University Press, Oxford/New York 2006).

${ }^{104}$ Clive M. Schmitthoff, 'The New Sources of the Law of International Trade' (1963) 15 International Social Science Journal 259-264; Berthold Goldman, 'Lex Mercatoria' (1983) 3 Forum Internationale 3-24; for more detail: Calliess and Zumbansen (2010), ch. 1.

105 Jürgen Habermas, The Postnational Constellation (MIT Press, Cambridge, MA 2001); Jürgen Habermas, 'A Political Constitution for the Pluralist World Society?' in Jürgen Habermas (ed) Between Naturalism and Religion Philosophical Essays (Polity, London 2008).

${ }^{106}$ William Twining, Globalisation and Legal Theory (Northwestern University Press, Evanston, IL 2000), above.

107 In the world of transnational governance ' $[\mathrm{t}$ ] he usual panoply of constitutional mechanisms of accountability and legitimacy which characterises liberal democratic constitutional systems is not necessarily available.' Julia Black and David Rouch, 'The development of global markets as rule-makers: engagement and legitimacy' (2008) Law and Financial Markets Review 218-233 (depicting the system of international financial governance to be distinct from nation state based understandings of governance), 224; see also Pierre-Hugues Verdier, 'Transnational Regulatory Networks and Their Limits' (2009) 34 Yale Journal of International Law 113-172, and the intriguing debate following this paper: http://opiniojuris.org/2009/04/09/transnational-regulatory-networks-andtheir-limits/ 
go to the heart of present legal-theoretical attempts to make sense of 'global governance' and that many still continue to address through the lens of the state. ${ }^{108}$ These questions arise, notably, around the 'politics of private law making' ${ }^{109}$ and as such concern primarily the constitutional dimensions of private ordering, that is, issues of accountability, legitimacy and democratic control. ${ }^{110}$ As increasingly specialised, functionally differentiated problem areas and spheres of human and institutional conduct evolve in response to a combination of external impulses and their own particular logics ${ }^{111}$, the law governing these constellations becomes deeply entwined in these complex, layered constitutions. ${ }^{112}$ The heterarchical and network

\begin{abstract}
${ }^{108}$ Wilhelm von Humboldt, The Sphere and Duties of Government (The Limits of State Action) [orig. German, 1792, transl. Joseph Coulthard jun.] (John Chapman, London 1854); Jean-Bertrand Auby, La globalisation, Le Droit et I'État (Montchrestien, Paris 2003), 95; Florian F. Hoffmann, 'In Quite a State: Trials and Tribulations of an Old Concept in New Times' in Russell A. Miller and Rebecca Bratspies (eds), Progress in International Law (Martin Nijhoff, The Hague 2008); Stephen Bell and Andrew Hindmoor, Rethinking Governance. The Centrality of the State in Modern Society (Cambridge University Press, Cambridge, UK 2009);
\end{abstract}

109 See only Daniela Caruso, 'Private Law and State-Making in the Age of Globalization' (2006) 39 New York University Journal of International Law \& Politics 1-74.

${ }^{110}$ For an insightful discussion, see Kenneth W. Abbott and Duncan Snidal, 'Strengthening International Regulation Through Transnational New Governance: Overcoming the Orchestration Deficit' (2009) 42 Vanderbilt Journal of Transnational Law 501-578, Colin Scott, 'Regulating private legislation' in Fabrizio Cafaggi and Horatia Muir-Watt (eds), Making European Law Governance Design (Edward Elgar, Cheltenham, UK 2008), and Colin Scott, 'Reflexive governance, meta-regulation and corporate social responsibility: the 'Heineken effect" in Nina Boeger, Rachel Murray and Charlotte Villiers (eds), Perspectives on Corporate Social Responsibility (Edward Elgar, Cheltenham 2008); see also Amiram Gill, 'Corporate Governance as Social Responsibility: A Research Agenda' (2008) 26 Berkeley Journal of International Law 452-478, 471-475, 471: "Corporate self-regulation and meta-regulation, read against the New Governance literature, capture a central element in the complexity of business law. That is, these regulatory patterns accompany socio-legal changes in market economies, highlighted by the fall of state authority and the rise of private ordering." See also Christopher M. Bruner, 'States, Markets, and Gatekeepers: Public-Private Regulatory Regimes in an Era of Economic Globalization' (2008) 30 Michigan Journal of International Law $125-176$ (discussing credit rating agencies and the Internet Corporation for Domain Names and Numbers-ICANN-as examples of 'public-private gatekeepers' and their government-like exercise of regulatory authority-id, at 129, 165).

${ }^{111}$ See the examples in Volkmar Gessner and Ali Cem Budak (eds), Emerging Legal Certainty: Empirical Studies on the Globalization of Law (Ashgate, Brookfield 1998), and Andreas Fischer-Lescano and Gunther Teubner, 'RegimeCollisions: The Vain Search for Legal Unity in the Fragmentation of Global Law' (2004) 25 Michigan J Int'l L 9991046.

112 Gunther Teubner and Peter Korth, 'Two Kinds of Legal Pluralism: Collision of Laws in the Double Fragmentation of World Society' in Margaret Young (ed) Regime Interaction in International Law: Theoretical and Practical Challenges (2009), Ms. at 5 (available at: http://papers.ssrn.com/sol3/papers.cfm?abstract id=1416041): 'Unitary global law reproduces itself through legal acts which are guided by different programs but are in the end oriented towards the binary code legal/illegal. The unity of global law is just not, as in the nation state, based on the consistency of legal norms structurally secured by the hierarchy of the courts: rather, it is process-based, deriving simply from the modes of connection between legal operations, which transfer binding legality between even highly heterogeneous legal orders.' 
dimensions of this functionalist evolution of law ${ }^{113}$ stands in stark contrast to the image of law as extending its regulatory grasp downward from the tip of a hierarchical pyramid into society: functionally differentiated law is forced to constantly embrace evolving institutional permutations ${ }^{114}$ that prove infinitely more complex and heterarchical than even institutional economics would have us believe. ${ }^{115}$ Like a veil, law lays itself onto the surfaces of the shifting institutional body, and through its semi-transparent, highly lacerable material it makes visible, and sensitizes the observer, to the anatomy of the evolving torso, its muscles, bones, joints, strains, injuries and lesions. ${ }^{116}$

\section{B. DEFINING LAW}

This image of law captures the functionalist attack on the keenly guarded bastion of legal formalism at the end of the $19^{\text {th }}$ century ${ }^{117}$ as much as the horror vacui that eventually caught up with the process of destruction as legal scholars immersed themselves in empirical foundations of law, only to realise that the edifice of law began to dissolve before their very eyes. ${ }^{118}$ The search for law in the face of its fall from unifying triumph into evaporation, helplessness, abuse and abolition ${ }^{119}$ inspired the post-WW II autopsy of positivist and natural

113 Walter W. Powell, 'Neither Market nor Hierarchy: Network Forms of Organization' (1990) 12 Research in Organizational Behavior 295-336; Karl-Heinz Ladeur, 'The Role of Contracts and Networks in Public Governance: The Importance of the "Social Epistemology" of Decision-Making' (2007) 14 Indiana Journal of Global Legal Studies 329-351

114 See, in this regard, Robert D. Cooter, 'Structural Adjudication and the New Law Merchant: A Model of Decentralized Law' (1994) 14 International Review of Law and Economics 215-231, 216: '...as economies become more complex, efficiency demands more decentralized lawmaking, not less.'

115 See eg, Douglass C. North, 'Institutions' (1991) 5 J Econ Persp 97-112; promising advances and further specifications are offered in Douglass C. North, Understanding the Process of Economic Change (Princeton University Press, Princeton/Oxford 2005), Oliver E. Williamson, 'The Economics of Governance' (2005) 95 American Economic Review 1-18, and Elinor Ostrom, 'Challenges and growth: the development of the interdisciplinary field of institutional analysis' (2007) 3 Journal of Institutional Economics 239-264.

${ }^{116}$ See also Reza Banakar, 'Law Through Sociology's Looking Glass: Conflict and Competition in Sociological Studies of Law' (2009) THe ISA Handbook in Contemporary Sociology 58-73, for an excellent discussion of the challenges for law to capture social reality.

117 See, eg: Roscoe Pound, 'Law in Books and Law in Action' (1910) 44 American Law Review 12; Felix Cohen, 'Transcendental Nonsense and the Functional Approach' (1935) 35 Columbia Law Review 809-849.

${ }^{118}$ Roscoe Pound, 'The Call for a 'Realist' Jurisprudence' (1931) 44 Harvard Law Review 706.

119 H.L.A. Hart, 'Positivism and the Separation of Law and Morals' (1958) 71 Harvard Law Review 593; Lon Fuller, 'Fidelity to Law - A Reply to Professor Hart' (1958) 71 Harvard Law Review 629-672 
law theories of law ${ }^{120}$ that eventually gave way to a radical opening of legal theory and doctrine to the diversity of existing social ordering systems. ${ }^{121}$ From this perspective, the evolution of law as a regulatory tool in the latter half of the $20^{\text {th }}$ century provides ample opportunities to reflect on the way in which law has been asserting itself as a reformist, emancipatory, empowering tool on the one hand ${ }^{122}$, and as a deeply violent, usurping, hegemonising force on the other. Indeed, its conflictual nature cannot be imagined without that which threatens to consume and suffocate it. The sobering fate of social-reformist legal theories in the aftermath of the regulatory welfare state ${ }^{123}$ and, in particular, their embrace of the functionalist enactment of the moderating or 'enabling state' at the end of the century ${ }^{124}$ should caution us against putting too much hope in law as a weapon, voice or as a tool of resistance. The turn and transformation of responsive ${ }^{125}$ and reflexive ${ }^{126}$ law programs in highly mature constitutional cultures into flexible regulatory programs that accompanied (and accommodated) a growing distrust in state regulation and political-reformist legal theory in the name of efficiency ${ }^{127}$ and 'good governance' present a formidable challenge to the post-Welfare state depictions of 'alternatives to law'. ${ }^{128}$ At the end of the $20^{\text {th }}$ century, the grand narratives of social order and

${ }^{120}$ Gustav Radbruch, 'Gesetzliches Unrecht und übergesetzliches Recht' (1946) 1 SJZ 105-108.

${ }^{121}$ Marc Galanter, 'Justice in many rooms: Courts, Private Ordering and Indigenous Law' (1981) $19 \mathrm{~J}$ Leg Pluralism 1-47; Gunther Teubner, 'Autopoiesis in Law and Society: A Rejoinder to Blankenburg' (1984) 18 Law \& Society Review 291-301.

${ }^{122}$ See for example, Günter Frankenberg, 'Down by Law: Irony, Seriousness, and Reason' (1988) 83 Northwestern University Law Review 360; Günter Frankenberg, 'Why Care? - The Trouble with Social Rights' (1996) 17 Cardozo Law Review 1365-1390.

${ }^{123}$ See the debate between Erhard Blankenburg, 'The Poverty of Evolutionism: a critique of Teubner's case for 'reflexive law" (1984) 18 Law \& Society Rev 273-289, and Gunther Teubner, 'Autopoiesis in Law and Society: A Rejoinder to Blankenburg' (1984) 18 Law \& Society Review 291-301.

${ }^{124}$ For a critique, see Kerry Rittich, 'Functionalism and Formalism: Their latest Incarnations in Contemporary Development and Governance Debates' (2005) 55 University of Toronto Law Journal 853-868.

${ }^{125}$ Philippe Nonet and Philip Selznick, Law and Society in Transition. Toward Responsive Law (Octagon Books, New York 1978)

${ }^{126}$ Gunther Teubner, 'Substantive and Reflexive Elements in Modern Law' (1983) 17 Law \& Society Review 239-285

${ }^{127}$ For a reminiscence, see Orly Lobel, 'The Paradox of Extralegal Activism: Critical Legal Consciousness and Transformative Politics' (2007) 120 Harvard Law Review 937-988

${ }^{128}$ See, for example, the contributions to Erhard Blankenburg and others (eds), Alternative Rechtsformen und Alternativen zum Recht (Jahrbuch für Rechtssoziologie und Rechtstheorie, Bertelsmann, Düsseldorf 1980). 
progress carry the stain of Eurocentrism and hegemony ${ }^{129}$, and the fate of law becomes fully caught up in this maelstrom. ${ }^{130}$ Its claim for authenticity becomes a matter of radical contestation as law's aspiration to rule, guide, direct and control is challenged by a fast proliferating host of sites of normative orders. ${ }^{131}$

Where does the progression of legal definitions in Table 1 leave us? Does the contradictory nature of the first four definitions leave the fifth as the only viable one?

Obviously, law's self-destruction began before globalisation. ${ }^{132}$ Globalisation, as alluded to in the introduction to this article, can provide a label to depict what should be seen as a further stage of reflection on the relationship between law and its other rather than as an endpoint of the possibility of law. The predominance of law's institutionalisation in the Western nation state during the $19^{\text {th }}$ and $20^{\text {th }}$ centuries not only casts a long shadow over our present attempts to imagine law, but it also is bound to make us blind to other, alternative approaches to political legitimacy and legal order. ${ }^{133}$ While the challenge of law in, or in relation to, the $20^{\text {th }}$ century welfare state is its functional diffusion and normative evaporation, that of the 'new developmental state' is a radical challenge to presuppositions regarding the role of the state or the meaning of public and private. ${ }^{134}$ To be sure, this temporalisation ('after' globalisation) indicates a paradigm shift, a conclusion and abdication of a dominant concept, rather than

129 Brillant: Dipesh Chakrabarty, Provincializing Europe. Postcolonial Thought and Historical Difference, 2nd ed. [orig. 2000] (Princeton University Press, Princeton, NJ 2007).

130 Boaventura de Sousa Santos, 'Law: A Map of Misreading. Toward a Postmodern Conception of Law' (1987) 14 Journal of Law \& Society 279; Sundhya Pahuja, 'Global Formations: IMF Conditionality and the South as Legal Subject' in Peter Fitzpatrick and Patricia Tuitt (eds), Critical Beings Law, Nation and the Global Subject (Ashgate, Aldershot 2004).

${ }^{131}$ Niklas Luhmann, Law as a Social System (K Ziegert transl., F Kastner, D Schiff, R Nobles, R Ziegert eds.) (Oxford University Press, Oxford/New York 2004).

${ }^{132}$ But see William Twining, Globalisation and Legal Theory (Northwestern University Press, Evanston, IL 2000).

133 Issa G. Shivji, 'Human Rights and Development: A Fragmented Discourse' in Peer Zumbansen and Ruth Buchanan (eds), Law in Transition: Human Rights, Development and Transitional Justice (Hart Publishing, Oxford, UK/Portland, OR 2010)

134 David Trubek and Alvaro Santos, 'Introduction: The Third Moment in Law and Development Theory and the Emergence of a New Critical Practice' in David Trubek and Alvaro Santos (eds), The New Law and Economic Development (Cambridge University Press, Cambridge 2006); David M. Trubek, 'Developmental States and the Legal Order: Towards a New Political Economy of Development and Law' (2008) University of Wisconsin Legal Studies Research Paper No 1075 http://ssrn.com/abstract=1349163 
demarcating a historical development of an institutional framework that would comprehensively replace the preceding models of the state and modes of legal thinking. ${ }^{135}$

Table 2: The Law and the State

\begin{tabular}{|l|l|l|l|}
\hline MODEL of STATE & Rule of Law & $\begin{array}{l}\text { Social State / } \\
\text { Welfare State }\end{array}$ & $\begin{array}{l}\text { Enabling State, } \\
\text { Moderator State, } \\
\text { Supervision State / } \\
\text { Civil Society, } \\
\text { Risk Society, } \\
\text { World Society }\end{array}$ \\
\hline MODEL of LAW & Formal & Substantive & Procedural \\
\hline LEGAL METHOD & Deduction & Balancing & Experimenting \\
\hline
\end{tabular}

The importance of this taxonomy of models of state, models of law and legal method lies in its promise of providing us with a tableau of law's evolution at least since the late $18^{\text {th }}$ century into the present. But, as noted, the implied idea of progress or, even of historical evolution is treacherous. While such historiography would allow us to trace the construction of conceptual frameworks, in our case the association of (changing) law with the (changing) state, it nevertheless runs the risk of mistakenly exaggerating that very nexus between law and the state. That is where the third column in Table 2 becomes central: following a dialectical logic, it should here provide for the negation of thesis (formal law) and antithesis (substantive law). Yet, what we see is the diffusion of categorical boundaries that we used to refer to in order to distinguish between different models of state and different models of law. Western legal theory, for much of the $20^{\text {th }}$ century, has occupied itself with the impossibility of distinguishing between 'public' and 'private' as a manifestation of the paradoxical foundation of law's legitimacy with reference to the separation of the state and the market, of politics and economics. ${ }^{136}$ Yet, it is this irresolvable tension between the public and the private ${ }^{137}$ that winds like a red thread through the evolution of models of state and law. The 'present' - which

135 For a parallel application of such a perspective, see Duncan Kennedy, The Rise and Fall of Classical Legal Thought (1975) (Beard Books, Cambridge, MA 2006).

136 Duncan Kennedy, 'The Stages of the Decline of the Public/Private Distinction' (1982) 130 University of Pennsylvania Law Review 1349-1357; Ernst-Wolfgang Böckenförde, 'The Significance of the Distinction between State and Society in the Democratic Welfare State of Today' in Ernst-Wolfgang Böckenförde (ed) State, Society and Liberty Studies in Political Theory and Constitutional Law (JA Underwood transl) (Berg, New York \& Oxford 1991)

137 Hannah Fenichel Pitkin, 'Justice: On Relating Public and Private' (1981) 9 Political Theory 327-352; see, of course, Hannah Arendt, The Human Condition (Chicago University Press, Chicago 1958). See also Carole Pateman, 'The Patriarchal Welfare State' in Amy Gutman (ed) Democracy and the Welfare State (Princeton University Press, Princeton, NJ 1988), and Iris Marion Young, Justice and the Politics of Difference (Princeton University Press, Princeton, NJ 1990). 
of course is only perceived as such today from our particular viewpoint, but is meant as the always inherent potentiality of state and society in the evolution of each ideal type of the state, and which is depicted in the third column -- might in the 'future' be revealed as the not-yet, as an immodest pretension of a stage of closure. But, that we don't know. For now, it signifies a moment of inability. The third column captures the impossibility of adequately rendering the present model of state. It gives expression to the inaptitude of applying categories of formal or substantive law to the proliferating sources and regulatory regimes of rule generation that apply to myriad social practices.

What this table tries to capture, then, is the association of a particular model of law (formal, substantive, procedural) and of legal methodology (deduction, balancing, experimenting) with a particular model of the state. This association is reflective of the tendency to imagine law in correlation with a historically evolving model of the state, for which we have in the West through the course of the twentieth century - been crafting labels such as the 'rule of law', the 'welfare state' and, into the present, for example the 'enabling state'. This association has been misleading in two ways: first, it suggests the false replacement of a 'previous' (eg the rule of law') by a 'succeeding' model (eg the 'social' or 'welfare state'), in other words, the end of one model and the beginning of the next. Such a depiction is misleading in that it overstates the development of a maturing human rights awareness and codification/institutionalisation - often associated with the emergence of the welfare state - by suggesting that the rule of law as a label does not encompass such an understanding of human rights. What this table then misrepresents is the irresolvable and creative tension between the models of the rule of law and the welfare state (and the associated models of law and legal methodologies): this tension is irresolvable because formal and substantive are two sides of law. The depiction of law as either 'formal' or 'substantive' in association with the rule of law or the welfare state is thus not an expression of historical progression, but is instead owed to the observation of which understanding of law dominated (over the other) in relation to a particular model of the state. What the labels depict, then, is less an objective reality of a particular type of state, but rather the dominant understanding of a certain type of state and its law. As such, the table seeks to capture the often polemical assertions of what kind of law is possible or impossible with regard to a particular model of the state.

The other way, in which the table's suggestion of models of law and state and respective methodologies is misleading, concerns the invisibilisation of the self-referential character of all three columns. Instead of depicting a clean, historical succession of paradigms of state and law, the table is meant to capture the present attempt, expressed in the third column, to make sense of already existing and competing definitions of the state, its law and its method. As such, the table recounts historically found, tentative assertions of the nexus between the state and the law only to show how our present efforts of understanding this nexus are shaped by the complex history of the association of different models of the state with evolving understandings of law.

Law's experimentation, captured in the third column of table 2, might be an adequate depiction of law as parasite, of a law that has no proper method of its own and that which follows a wide- 
ranging variety of demands. But law's experimentation might also be the expression of law in search of itself, of a law that cannot be sure of itself, its identity, its potential and foundations. Its stubborn self-reassertion, then, happens only from an ironical stance. Authority gained from the state has become a fleeting reassurance at best, considering the diversification and decentralisation of rule making and enforcement in modern states. Authority gained by an appeal to a higher order is inevitably based on the belief in a functioning, validating and legitimating process of interpretation, application and implementation. As such, issues of authority become irreversibly tied to issues of distribution ${ }^{138}$, merging the 'models' of the rule of law and the social/welfare state into a paradoxical concept, whose historical appearance is merely contingent. It then becomes clear that what comes 'after' the welfare state might either be the super-welfare state or its demise, the neo-liberal enabling state: as models, however, they are but labels for a particular stage of institutional evolution. They say little if anything about the law of the present.

\section{Places AND Spaces, Whither LaW?}

With legal imagination haunted by images of a world of injustice, unequal distribution and grave rights abuses ${ }^{139}$, the question becomes whether there is any room, role or even a need for law in a globalised world. This question lies at the bottom of the current engagement of lawyers with global governance issues. As identified in the preceding section, this inquiry cannot be isolated from the struggle for law that has so far been identified with the state. The central thesis of this paper is that this alleged crisis of law and legal regulation, whether depicted as a loss of state sovereignty or as a problem of lacking (democratic, political) accountability $^{140}$ and legitimacy ${ }^{141}$, should instead be understood as a particular amplification of a fundamental problem with law. In that respect, it can be shown that many of our present concerns about the fate of law in relation to a continuing transformation of the state in relation to contemporary forces or processes of globalisation or transnationalisation and resulting contestations of democracy, legitimacy and accountability must be assessed against the background of a reconstruction of legal evolution in the national, local context. Without

\footnotetext{
138 Nancy Fraser and Axel Honneth, Redistribution or Recognition? A Political-Philosophical Exchange (Verso, London 2003).

${ }^{139}$ Upendra Baxi, The Death of Human Rights, 2nd ed. (Oxford University Press, Oxford and New York 2005).

140 Jerry Louis Mashaw, 'Accountability and Institutional Design: Some Thoughts on the Grammar of Governance' (2007) Yale Law School Research Paper No 116 http://papers.ssrn.com/abstract=924879

141 Julia Black, 'Constructing and Contesting Legitimacy and Accountability in Polycentric Regulatory Regimes' (2008) LSE Law, Society and Economy Working Papers 2/2008 http://ssrn.com/abstract=1091783, associating legitimacy and accountability concerns of transnational regulatory regimes with a set of "functional, democratic, normative" challenges.
} 
suggesting that the legitimacy and regulatory challenges connected with the 'amorphous' concept of global governance ${ }^{142}$ are simple restatements or mirror reflections of locally experienced moments of 'exhaustion' ${ }^{143}$, there is a particular role to be played by local, domestic regulatory experiences for the conceptualisation of global governance regimes. The discussion focusing on the role of law occupies a particularly challenging place in this inquiry, in particular because the rise of globalisation is so often associated with the demise of law ${ }^{144}$ and with an immense pressure on law and legal institutions. Instead, globalisation can be understood as an invitation to reflect on the connections between our attempts to make sense of a fragmented global, normative order and our particular, yet anything but homogenous experiences with law and regulation on the national level. In short, then, the argument is that globalisation does not pose a first or a new advent of a 'crisis' of law, understood as a tool of regulation. Instead, the varied history of law reveals the always inherent combination of hubris and fragility, violence and vulnerability that underlies the idea and experience of law. This becomes particularly clear where transnational efforts of 'improving' the legal conditions in vulnerable contexts such as labour law have been encountering the need to develop a better understanding of both the power dynamics at play between the norm-exporting and the normreceiving country and the differences in the regulatory framework on the ground. ${ }^{145}$

Moreover, while there is much to learn from studying law against the background of a particular, national, historical context ${ }^{146}$, the transnational constellation further exacerbates the scope of this inquiry. Much suggests that the particular nature of the transnational arena

\footnotetext{
${ }^{142}$ For a lament of the concept's shortcomings in providing guidance for the development of sustainable and effective regulatory instruments, see Armin Bogdandy, Philipp Dann and Matthias Goldmann, 'Developing the Publicness of Public International Law' (2008) 9 German Law Journal 1375-1400; in contrast, see David Held, 'Reframing Global Governance: Apocalypse Soon or Reform!' in David Held and Anthony McGrew (eds), Globalization Theory Approaches and Controversies (Polity, London 2007), at 245-6, 249-254, and Mathias KoenigArchibugi, 'Global governance' in Jonathan Michie (ed) The Handbook of Globalisation (Edward Elgar, Cheltenham, UK 2003), highlighting the interdisciplinary challenges that are captured in the term.
}

${ }^{143}$ Jürgen Habermas, 'The New Obscurity: The Crisis of the Welfare State and the Exhaustion of Utopian Energies [1985]' in Jürgen Habermas (ed) The New Conservatism Cultural Criticism and the Historians' Debate [ed and transl by Shierry Weber Nicholsen] (MIT Press, Cambridge, MA 1989)

${ }^{144}$ See, for example, the intriguing melancholic observation by Niklas Luhmann, Law as a Social System (K Ziegert transl., F Kastner, D Schiff, R Nobles, R Ziegert eds.) (Oxford University Press, Oxford/New York 2004), 497.

145 Boaventura de Sousa Santos, 'The Processes of Globalisation' (2002) Eurozine http://www.eurozine.com/pdf/2002-2008-2022-santos-en.pdf, 28.

\footnotetext{
${ }^{146}$ In this regard, see the helpful comparative reconstructions of public and private law concepts by Nils Jansen and Ralf Michaels, 'Private Law and the State. Comparative Perceptions and Historical Observations' (2007) 71 Rabels Zeitschrift für ausländisches und internationales Privatrecht [RabelsZ] 345-397, reprinted in: Jansen \& Michaels eds., Beyond the State: Rethinking Private Law (2008), 15-67
} 
defeats our attempts at understanding the relation between the national and the 'post-national constellation ${ }^{147}$ as a linear one - either on a chronological or a systematic level. ${ }^{148}$ But, at the same time, the evolving transnational nature of regulatory regimes as, for example, in corporate $\operatorname{law}^{149}$ or, again, in labour law ${ }^{150}$, presents itself not as an opposition to or the negation of the possibility of extending the reach of legal regulation, but as a challenge to reassert the place and role of law in response to the thesis of law's demise in an era of globalisation. Reconceiving law as transnational suggests that domestic experiences with 'law' are crucial reference points. Yet, they cannot serve as reference points of institutional or normative design, which we could simply 'rediscover' and amplify for a transposition into the transnational arena. Instead, this approach must point towards two investigative strands. One is that the inquiry into the evolution and, eventually, crisis of law as regulation of social activity has to attempt the reconstruction as an ironic project that is concerned with the meaning and aspiration of law as such: it is here where the positing of law is directly challenged by the prospect of its impossibility, by its fundamental negation. This constellation can be grasped as the relation or tension between law and non-law, between legality and legitimacy, between law and justice, society, or other. ${ }^{151}$ One strand of the ensuing inquiry is formed by the reconstruction of local (eg national) experiences with law as constantly challenged by its opposite or its foundations, embeddedness or contestations. ${ }^{152}$

${ }^{147}$ Jürgen Habermas, The Postnational Constellation (MIT Press, Cambridge, MA 2001)

${ }^{148}$ See the succinct observations by William Twining, Globalisation and Legal Theory (Northwestern University Press, Evanston, IL 2000) with regard to the challenges to jurisprudence and by Jürgen Osterhammel and Niels $\mathrm{P}$. Petersson, Globalization: A Short History (Princeton University Press, Princeton, NJ/Oxford, UK 2004) with regard to the interdisciplinary challenges of studying and deciphering 'globalization'. "The fact that historians assert with calm detachment that this phenomenon has existed for a long time does not preclude the need to make a political assessment of its impact on the present." Id., at 150.

149 Simon Deakin, 'Reflexive Governance and European Company Law' (2007) CLPE Research Paper Series (http://wwwcomparativeresearchnet/papersjsp) \& Cambridge Centre for Business Research, Working Paper No 346 http://www.cbr.cam.ac.uk/pdf/wp346.pdf; Peer Zumbansen, 'The Parallel Worlds of Corporate Governance and Labor Law' (2006) 13 Indiana Journal of Global Studies 261-312

${ }^{150}$ Adelle Blackett, 'Global Governance, Legal Pluralism and the Decentered State: A Labor Law Critique of Codes of Corporate Conduct' (2001) 8 Indiana Journal of Global Legal Studies 401-447; Harry W. Arthurs, 'Labor Law Without the State' (1996) 46 University of Toronto Law Journal 1-45

151 See, for example, David Trubek, 'Toward a Social Theory of Law: An Essay on the Study of Law and Development' (1972) 82 Yale Law Journal 1-50; Robert M. Cover, 'Nomos and Narrative' (1983) 97 Harvard Law Review 4-68; Jacques Derrida, 'Force of law' (1990) 11 Cardozo Law Review 919-1045. See also Gunther Teubner, 'Self-subversive Justice: Contingency or Transcendency Formula of Law?' (2009) 72 Modern Law Review 1-23.

${ }^{152}$ See, for example, Boaventura de Sousa Santos, 'Law: A Map of Misreading. Toward a Postmodern Conception of Law' (1987) 14 Journal of Law \& Society 279. 
The second investigative strand is to return to the original starting point of our reflections of how globalisation challenges law. In this dimension we are concerned with the task of adequately incorporating or, perhaps only acknowledging, the gap between the particular context in which norms and the normative environments have evolved locally on the one hand, and the emerging, allegedly unruly spaces of normative order on the global level on the other. As indicated before, a reflection on the field of transnational law, a notion which Jessup offered in the 1950s to capture the hybrid regulatory space between the national and the internationa ${ }^{153}$, should lead to its unfolding as a methodological device rather than to a demarcation of a more or less definable legal field. Approaching transnational law from a methodological perspective should help us to refrain from too quickly depicting the 'transnational' as a distinct regulatory space, which differs from the national and the international because of its de-territorialised scope and its hybrid, including mixed publicprivate, constitution. Instead, transnational law can be perceived as a particular perspective on law as part of a society, which itself cannot sufficiently be captured by reference to national or de-nationalized boundaries.

This depiction most certainly echoes a systems-theoretical understanding of a functionally differentiated world society where law constitutes one among other particularly coded communications. Intrigued by Luhmann, who in concluding his seminal treatise on the "law of society', famously questioned the survival of law in a global context ${ }^{154}$, other scholars in his footsteps, by pointing to the normative evolutions occurring within emerging transnational regulatory regimes, have been making a number of constructive suggestions to think 'law without the state'. ${ }^{155}$

Yet, it might be possible to push these advances even further. The attempts at understanding transnational law as a methodological inquiry into the nature of norms reconnect this inquiry with a longstanding investigation into the nature of law - and its contestations. The transnational dimension, then, does not only arise with respect to territorial, or jurisdictional confines, but also from the perspective of following the institutional modes of norm creation deep into highly specialized areas of societal activity. It is here where the idea of transnational law reveals its ambivalent relationship to the 'old' and the 'new': on the one hand, transnational law appears to be embedded in and to be unfolding against the background of a

\footnotetext{
153 Philip C. Jessup, Transnational Law (Storrs Lectures in Jurisprudence at Yale Law School, Yale University Press, New Haven 1956)

${ }^{154}$ Niklas Luhmann, Law as a Social System (K Ziegert transl., F Kastner, D Schiff, R Nobles, R Ziegert eds.) (Oxford University Press, Oxford/New York 2004), ch. 12
}

\footnotetext{
${ }^{155}$ See the contributions to Gunther Teubner (ed), Global Law Without A State (Ashgate, Aldershot 1997); see also the tour d'horizon (de force?) by Andreas Fischer-Lescano and Gunther Teubner, 'Regime-Collisions: The Vain Search for Legal Unity in the Fragmentation of Global Law' (2004) 25 Michigan J Int'I L 999-1046 with regard to particular regulatory regimes.
} 
state-centred understanding of a legal order, while on the other hand, the concept is connected to the longstanding and ever-increasing experiences of normative pluralism that sit uncomfortably with systematisations of law as necessarily connected to the state. ${ }^{156}$ From the point of view of systems theory, these differentiated 'areas' are constituted in functionalist terms: as the functional differentiation of society leads to a radical unfolding of society as world society, the challenge for law consists in existing and operating in a simultaneous recognition and disrespect vis-à-vis a known, sophisticated institutional and normative framework. ${ }^{157}$ The current assertions, say, on this and that side of the Atlantic of a so-called 'global' administrative or 'general public law' speak volumes of this challenge. ${ }^{158}$

While this uncoupling of social systems from a state-associated framework of political, economic and legal order certainly presents a dramatic challenge to state-centred theories of law, its real gist in fact lies elsewhere. The - for lawyers - uneasy relationship between 'society' and 'world society', between the national and the global, that is the, transnational, should in fact not be seen as a threat but instead as an element inherent to the constitution of legal spaces. From this perspective, transnational refers to the 'other' of the law, which challenges but simultaneously recognises its locally learned relations to concrete structures of embeddedness, to particular experiences of historical evolution and contextual differentiation. Transnational law, then, is a way of questioning and reconstructing the project of law between places and spaces, where - in other words - places and spaces do not necessarily have to map onto territorial or geographical sub-strata or be divisble somehow into national or international. This perspective raises hopes for a realization of the project of law, whereby law would necessarily have to be understood as having a recoverable, revivable emancipatory potential. But, what if that were not the case and questions of democratic governance would attain an endlessly hollow sound in a globalised world? ${ }^{159}$ What if the fragility of law would win the day, if law's corruptibility would prevail over its absurdly stubborn insistence on its existence, its very raison d'être?

${ }^{156}$ Craig M. Scott, "Transnational Law' as Proto-Concept: Three Conceptions' (2009) 10 German Law Journal 859876,862

${ }^{157}$ Niklas Luhmann, 'Die Weltgesellschaft' (1970) 57 Archiv für Rechts- und Sozialphilosophie 1; Niklas Luhmann, 'The World Society as a Social System' (1982) 8 International Journal of General Systems 131-138

${ }^{158}$ See von Bogdandy, Dann \& Goldmann, supra, note 3, and Nico Krisch, Benedict Kingsbury and Richard B. Stewart, 'The Emergence of Global Administrative Law' (2005) 68 Law and Contemporary Problems 15; for challenging critiques, see Carol Harlow, 'Global Administrative Law: The Quest for Principles and Values' (2006) 17 European Journal of International Law 187-214, and B.S. Chimni, 'Cooption and Resistance: Two Faces of Global Administrative Law' (2005) IIL International Law and Justice Working Papers 2005/16

${ }^{159}$ Alexander Somek, 'The argument from transnational effects II: Establishing transnational democracy' (2010) 16 European Law Journal 375-395 
Again, the 'outside' perspective of globalisation proves surprisingly helpful in further sharpening our investigative focus: the extremely unsure fate of social and political rights in transnational spaces underscores the challenge that lawyers face in pursuing law as a critical project in an increasingly integrated world. ${ }^{160}$ In the emerging global spaces of highly specialized functional societal activities, both legal and political power have faired very differently from economic power. The weakness of the former in relation to the long undeterred success of the latter is reflected in the persistent absence of an effective global legal-political order. In this space, the transposition of legal instruments and concepts, which were developed on the domestic level, onto the level of regulating cross-border transactions both public and private ${ }^{161}$ - occurs as a translation exercise. Not only is the institutional crystallization of the global space intimately interwoven into local structures while facilitating a disembedded self-regulatory, highly dynamic space, but the same tension between place and space repeats itself with regard to the normative dimension. ${ }^{162}$

\section{THINGS WE LOST?}

The preceding observations point to an assessment of things we (allegedly) lost as a layered account that is informed by a double perspective on legal memory. One story of loss is directly linked to the difficulties of translating both institutions and concepts from the national to the transnational level. This well-known story, however, is quite misleading: it is misleading in the sense that it renders invisibile the inherent fragility of law that has always been there and that thus existed 'before' globalisation. ${ }^{163}$ The already noted laments concerning the alleged erosions of sovereignty, of legal hierarchy and unity, of democracy and legitimacy, that are seen in close connection to the state's loss of regulatory ability in particular to govern transnational activities, can now be read as a reversal of what has been a longstanding critical stance towards law. The depiction of an allegedly external influence, sub verbo globalisation, which comes over nation states to subdue national governments and political actors from the outside by offsetting previously existing institutional and normative arrangements obscures the degree to

\footnotetext{
${ }^{160}$ Robert Wai, 'Countering, Branding, Dealing: Using Economic and Social Rights in and around the International Trade Regime' (2003) 14 European Journal of International Law 35-84; Dan Danielsen, 'Local Rules and a Global Economy: An Economic Policy Perspective' (2010) 1 Transnational Legal Theory 49-115, 65-68.

${ }^{161}$ See already Philip C. Jessup, Transnational Law (Storrs Lectures in Jurisprudence at Yale Law School, Yale University Press, New Haven 1956).

${ }^{162}$ David Schneiderman, 'Transnational Legality and the Immobilization of Local Agency' (2006) 2 Annual Review of Law and Social Sciences 387-408, 404: "What is called for here is an opening up, rather than concealment, of the spaces and places through which the legal order of economic globalization can be politicized, interrogated, and rolled back." See also Danielsen, 'Local Rules and a Global Economy', above.

${ }^{163}$ Robert M. Cover, 'Violence and the Word' (1986) 95 Yale Law Journal 1601-1629.
} 
which all such arrangements had always been contestable and fragile from the beginning. ${ }^{164}$ Reminding us of Martti Koskenniemi's depiction of the reversal of emergency and normal in the justificatory debates over the Kosovo intervention ${ }^{165}$, the image of globalisation as threat to the sovereignty of the state and the unity of law washes over the highly contested grounds on which the two have always been resting. ${ }^{166}$ In order to explore this contention further, the next section briefly ties the current investigations about the fate of law in the transnational context back to the critique levelled against the regulatory state during the 1970s and 1980s.

\section{A. LAW AS NON-LAW}

Current research into the breathtaking development of transnational regulatory regimes prompts intriguing parallels to previous inquiries into the driving forces of legal regulation, in particular the development of 'legal pluralism' and 'law and society' in the 1970s and 1980s. For one, legal pluralists and law and society scholars crucially contributed to a better understanding of the 'semi-autonomous' nature of legal fields: as pioneered in Sally Falk Moore's analysis of law in her 1976 article ${ }^{167}$, law is understood as constituted in part by social norms, routines, customs and practices and in part by hard legal regulation. The ensuingnotion of law as a semiautonomous field proved of vital importance in opening our eyes to the intricate relations between the regulator and concrete, local, intimate social spaces. ${ }^{168}$ As well, striving for alternatives to the at times heavy-handed social engineering by the legal machinery, scholars called for extra-legal activism ${ }^{169}$ and delegalisation. ${ }^{170}$

164 Saskia Sassen, 'The State and Globalization' in Joseph S. Nye and John D. Donahue (eds), Governance in a Globalizing World (Brookings Institution, Washington D.C. 2000); Alfred Aman Jr., 'Law, Markets and Democracy: A Role for Law in the Neo-Liberal State' (2007) 51 New York Law School Review 802.

165 Martti Koskenniemi, 'The Lady Doth Protest Too Much'. Kosovo, and the Turn to Ethics in International Law' (2002) 65 Modern Law Review 159-175

166 Peter Fitzpatrick, 'Terminal Legality? Human Rights and Critical Being' in Peter Fitzpatrick and Patricia Tuitt (eds), Critical Beings Law, Nation and the Global Subject (Ashgate, Aldershot 2004), 128: "With the rule of law, then, there can be no thing 'before' the law, nothing that rules with, through or instead of it. It presents itself as 'pure' or empty form devoid of 'significance' as to its content."

167 Sally Falk Moore, 'Law and Social Change: the semi-autonomous field as an appropriate subject of study' (1973) 7 Law \& Society Review 719-746

${ }^{168}$ For a discussion and elaboration, see only John Griffiths, 'What is Legal Pluralism?' (1986) 24 Journal of Legal Pluralism and Unofficial Law 1-55

${ }^{169}$ For a brief historical account, see Orly Lobel, 'The Paradox of Extralegal Activism: Critical Legal Consciousness and Transformative Politics' (2007) 120 Harvard Law Review 937-988. 
Such a growing understanding of the tensions between 'lifeworld and system ${ }^{171}$, 'the raw and the cooked' ${ }^{172}$, or 'core and periphery' ${ }^{173}$ would soon become instrumental in the critical assessment of the role of legal regulation in a highly pluralistic society during the middle of the $20^{\text {th }}$ century, which until then had remained very much within the intellectual and conceptual confines of Max Weber's distinction between substantive and formal rationalities of law. ${ }^{174}$ In his astute analysis of law's evolution from substantive to formal rationality along with the emergence of the bureaucratic rule of law, Weber had identified on the one hand the stabilizing role of law for the conduct of commercial (and other) affairs, while, on the other, he had emphasised the potentially harmful effects of ever-recurring anti-formal tendencies on the body and practice of law. ${ }^{175}$ Weber's sensibility to the contestations -- the anti-rational, material challenges -- to the aspiringly formal edifice of law ${ }^{176}$ turned out to foretel the ensuing evolution of legal regulation well into the highly sophisticated regulatory architectures of Western welfare states ${ }^{177}$, plagued by a purposive and intentional regulatory overdrive. ${ }^{178}$ It comes as no surprise, then, that the reflection on the place of law in a canon of voices of social

\footnotetext{
${ }^{170}$ Marc Galanter, 'Justice in many rooms: Courts, Private Ordering and Indigenous Law' (1981) $19 \mathrm{~J} \mathrm{Leg} \mathrm{Pluralism}$ $1-47$

${ }^{171}$ Jürgen Habermas, The Theory of Communicative Action (transl. Thomas McCarthy) (Polity, Cambridge 1984)

${ }^{172}$ Claude Lévi-Strauss, The Raw and the Cooked [orig. French 1964] (Penguin, New York 1969)
}

173 Boaventura de Sousa Santos, 'The Processes of Globalisation' (2002) Eurozine http://www.eurozine.com/pdf/2002-2008-2022-santos-en.pdf, 3.

${ }^{174}$ Max Weber, On Law in Economy and Society (transl. from the German Wirtschaft und Gesellschaft, 2nd ed., 1925, by E.Shils and M.Rheinstein, edited/annotated by M.Rheinstein) (Simon Schuster, New York 1967), 301, 321: "The law is drawn into antiformal directions, moreover, by all those powers which demand that it be more than a means of pacifying conflicts of interests."

${ }^{175} \mathrm{Id}$.

${ }^{176}$ See only David Trubek, 'Max Weber on Law and the Rise of Capitalism' (1972) Wisconsin Law Review 720-753.

177 Gunther Teubner, 'Substantive and Reflexive Elements in Modern Law' (1983) 17 Law \& Society Review 239285, 253: "Substantive rationality emerges in the processes of increasing state regulation. It is commonly associated with the growth of the welfare state and state intervention in market structures [...] The justification of substantive law is to be found in the perceived need for collective regulation of economic and social activities to compensate for inadequacies of the market."

178 Id., at 254: "Substantive Law is realized through purposive programs and implemented through regulations, standards, and principles." 
ordering that lawyers and social theorists in North America were concerned with ${ }^{179}$, was somewhat echoed by the critique of 'instrumental' and 'regulatory' law in an overly zealous welfare state apparatus in Western Europe. ${ }^{180}$

On both sides of the Atlantic, the responses to the financially and normatively exhausted welfare state ${ }^{181}$ soon split into progressive ${ }^{182}$ and conservative ${ }^{183}$ camps. This context is worth bearing in mind when assessing today's academic and political proposals in the wake of the financial crisis. In the context of the late 1970s and early 1980s, which saw a far-reaching crumbling of social-democratic policy and a growing scepticism with Keynesian economics, a fairly ambitious theoretical proposal was made that aimed at the resituating of law in a more accentuated model of society: in this model, which did not lend itself to a straight-forward ideological appropriation, society is composed of intersecting, while separated, communications that are each constituted by a distinct terminology ('code'). Law was to be understood as one of these social systems - along with the 'economy', with 'politics', 'religion', or 'art'. ${ }^{184}$ On this basis, the concept of 'reflexive law' was proposed as a form of law marked above all by a crucial exposure to and immersion into its surrounding systems, while it simultaneously remained 'operationally' closed. Due to its 'cognitive' openness, however, law must constantly receive impulses (or 'irritations') and, relying on its autopoietic nature, formulate legal responses -- ie continue its systematic operation - in the context of a constantly changing environment. In the face of the weakening welfare state and the growing frustration with ineffective, undemocratic, over-generalizing and paternalising regulatory laws ${ }^{185}$, the

${ }^{179}$ See, e.g., Philip Selznick, Law, society, and industrial justice (Yale University Press, New Haven, CT 1969).

180 Rüdiger Voigt (ed), Verrechtlichung (Athenäum, Königstein 1980); Karl-Heinz Ladeur, '"Abwägung" - ein neues Rechtsparadigma? Von der Einheit der Rechtsordnung zur Pluralität der Rechtsdiskurse' (1983) 69 ARSP 463-483; Gunther Teubner, 'Regulatory Law: Chronicle of a Death Foretold' (1992) 1 Social \& Legal Studies 451

181 Jürgen Habermas, 'The New Obscurity: The Crisis of the Welfare State and the Exhaustion of Utopian Energies [1985]' in Jürgen Habermas (ed) The New Conservatism Cultural Criticism and the Historians' Debate [ed and transl by Shierry Weber Nicholsen] (MIT Press, Cambridge, MA 1989)

${ }^{182}$ Hubert Rottleuthner, 'The Limits of Law: The Myth of a Regulatory Crisis' (1989) 17 Int'I J Sociol L 273

183 Friedrich A. Hayek, The Mirage of Social Justice [Law, Legislation and Liberty. A new statement of the liberal principles of justice and political economy, vol. 2] (The University of Chicago Press, Chicago 1976)

${ }^{184}$ Niklas Luhmann, Rechtssoziologie (1980), 3. Aufl. (Westdeutscher Verlag, Opladen 1987); Niklas Luhmann, 'Law as a Social System' (1989) 83 Northwestern University Law Review 136-150; Niklas Luhmann, Law as a Social System (K Ziegert transl., F Kastner, D Schiff, R Nobles, R Ziegert eds.) (Oxford University Press, Oxford/New York 2004)

${ }^{185}$ Teubner (note 180) 
concept of reflexive law was offered to explain the particular challenge and form of legal regulation in a complex world. Its contested ${ }^{186}$ core consisted of understanding law as being taken out of a learned institutional context made up of official institutions authoritatively creating state-originated laws and, instead, forced to reassert itself in highly diversified complex environments. This radicalization of law's functional orientation constituted a new stage in the assessment of law's institutional form, as it has been learned over time. Whereas law is still today most often associated with the state, already the legal sociological work at the turn of the century as well as the legal pluralist work since the 1960s and 1970s had long questioned the law-state nexus.

\section{B. The Amnesia of Transnational Regulation}

But, reflexive law came at a price, as its methodological orientation turned out to be highly attractive to those who wanted to deconstruct the state in the interest of market liberalisation. The turn away from the state and to the market at the end of the $20^{\text {th }}$ century can be seen as smartly employing the very methodological orientations that had informed the reconstructive legal projects in the face of a financially and normatively exhausted welfare state ${ }^{187}$ in the 1980s. The fragile reconstructions of law through the concepts of responsive or reflexive law on both sides of the Atlantic eventually fed into a large-scale rejection of state 'intervention' all throughout the 1980s and 1990s. When politically progressive scholars in the 1970s and 80s had turned to alternative modes of legal regulation seeking to translate law's generality into contextual, learning-oriented forms of socio-legal regulation, they had hoped to save the political ambitions of the welfare state, while continuing the socio-political debate over the substance and direction of political intervention. ${ }^{188}$ In contrast, both today's neo-formalism and today's neo-functionalism threatens to cut the ties between the current quest to answer the challenges of globalisation and the previous struggles over law and politics. Its proponents characterise legal regulation as inappropriately policy-driven and as undue infringement of the societal actors' capacity to regulate their own affairs autonomously. ${ }^{189}$ Boaventura de Sousa

${ }^{186}$ Erhard Blankenburg, 'The Poverty of Evolutionism: a critique of Teubner's case for 'reflexive law" (1984) 18 Law \& Society Rev 273-289

187 Jürgen Habermas, 'The New Obscurity: The Crisis of the Welfare State and the Exhaustion of Utopian Energies [1985]' in Jürgen Habermas (ed) The New Conservatism Cultural Criticism and the Historians' Debate [ed and transl by Shierry Weber Nicholsen] (MIT Press, Cambridge, MA 1989).

188 Rudolf Wiethölter, 'Social Science Models in Economic Law' in Terence Daintith and Gunther Teubner (eds), Contract and Organisation Legal Analysis in the Light of Economic and Social Theory (Walter de Gruyter, Berlin/New York 1986); Rudolf Wiethölter, 'Materialization and Proceduralization in Modern Law' in Gunther Teubner (ed) Dilemmas of Law in the Welfare State (Walter de Gruyter, Berlin/New York 1986)

${ }^{189}$ See, for example, Robert E. Scott and George G. Triantis, 'Anticipating Litigation in Contract Design' (2006) 115 Yale Law Journal 814-879. 
Santos aptly captured this development in the following observation: "In a model based on privatization, private initiative and market supremacy, the principles of order, reliability, and trust cannot be commanded by the state. They can only come from the law and the judicial system, as a set of independent and universal systems which create standard expectations and resolve litigation through legal frameworks which are presumed to be understood by everyone." 190

With the renaissance of neo-formalism and neo-functionalism, which have been characterising legal policy in recent years, a heavy reliance on arguments of 'necessity,' of 'objectivity' and 'naturalness' came to prepare the ground for a functionalist interpretation and application of legal norms in politically charged contexts experiencing fundamental shifts from public to private regulation. The attack on contract adjudication and governmental 'intervention' that accompanied these developments regularly rested on an understanding of the market as apolitical, a-historic and quasi-natural. ${ }^{191}$ This depiction of the market and the state as separate worlds formed troubling alliances with policy recommendations promoting the privatisation of public services that were often fuelled by arguments of efficiency and cost reduction. ${ }^{192}$ Yet, whether or not, and in which forms, private actors assume formerly public regulatory functions, represents the outcome of political choices and of other socio-economic developments at both the national and transnational level. ${ }^{193}$ The allegedly available 'fresh start' for societal selfregulation without state interference -at least as it was widely perceived until the outbreak of the 2007 financial crisis - stood in stark contrast to the observations made many decades ago, that when market actors are enabled and empowered to exercise their private autonomy they are exercising this freedom based on public deliberation and consensus. ${ }^{194}$

While there is considerable reason to believe, today, that we have entered a stage in the assessment of state and market where we have to carefully turn our attention again to the long

190 Boaventura de Sousa Santos, 'The Processes of Globalisation' (2002) Eurozine http://www.eurozine.com/pdf/2002-2008-2022-santos-en.pdf, 12

${ }^{191}$ Frank H. Knight, 'Some Fallacies in the Interpretation of Social Cost' (1924) 38 Quarterly Journal of Economics 582-606. "The system as a whole is dependent on an outside organization, an authoritarian state, made up also of ignorant and frail human beings, to provide a setting in which it can operate at all." Id.

192 For a critique, see Alfred C. Aman Jr., 'The Limits of Globalization and the Future of Administrative Law: From Government to Governance' (2001) 8 Indiana Journal of Global Legal Studies 379-400.

193 This led Philip Jessup to his capturing three dramas about constellations within and beyond the nation state that involve parallel questions of democracy and participation. See PHILIP C. JESSUP, TRANSNATIONAL LAW (STORRS Lectures in Jurisprudence at Yale LaW School, Yale University Press, NeW Haven 1956).

194 Morris R. Cohen, 'Property and Sovereignty' (1927) 13 Cornell Law Quarterly 8-30. 
and winding history of this relationship (between state and market) ${ }^{195}$, the identification of starting points for a reconstructive project is far from obvious. ${ }^{196}$ As the treacherous denationalisation $^{197}$ of regulatory areas continues to pose tremendous conceptual problems for state-based theories of law, we must aim at combining our methodological inquiry into the nature of transnational law with a bold reconstruction of critical perspectives from which to discuss the need for 'better', 'more efficient', 'tougher' etc regulation, that is needed today in the face of what continues to unfold as a dramatic financial and economic crisis.

\section{Transnational Governance Regimes as Cases in Point of Post-Regulatory LaW}

As is evidenced for example by the case of corporate governance regulation, many of today's regulatory regimes are irreversibly transnational and hybrid in nature. ${ }^{198}$ While we continue to study them through nationally oriented textbooks and case law, we soon learn how the rules and instruments we are dealing with are products of a far-reaching, fundamental transformation of the regulatory landscape. ${ }^{199}$ As corporate law is being shaped by a complex mix of public, private, state-based and non-state-based norms, principles and rules, generated, disseminated and monitored by a diverse set of actors ${ }^{200}$ and experts ${ }^{201}$, even the most casual

\footnotetext{
195 See eg, Paul Krugman, The Return of Depression Economics and the Crisis of 2008 (Norton, New York \& London 2009), Robert Skidelsky, Keynes. The Return of the Master (Allen Lane, London 2009) and Christian Marazzi, The Violence of Financial Capitalism (Edizioni Casagrande, Bellinzona, Switzerland 2010).
}

196 See, for example, Jens Beckert, 'The Great Transformation of Embeddedness. Karl Polanyi and the New Economic Sociology' (2007) Max-Planck-Institut für Gesellschaftsforschung/Max-Planck-Institute for the Study of Societies, MPIfG Discussion Paper 07/1 ; Michael J. Piore, 'Second Thoughts: On Economics, Sociology, Neoliberalism, Polanyi's Double Movement and Intellectual Vacuums' (2008) Society for the Advancement of Socio-Economics, Presidential Address July 22

197 Saskia Sassen, 'Globalization or denationalization?' (2003) 10 Review of International Political Economy 1-22; see also Saskia Sassen, 'The Embeddedness of Electronic Markets: The Case of Global Capital Markets' in Karin Knorr Cetina and Alex Preda (eds), The Sociology of Financial Markets (Oxford University Press, Oxford, UK/New York, NY 2005).

${ }^{198}$ David Vogel, 'The Private Regulation of Global Corporate Conduct' in Walter Mattli and Ngaire Woods (eds), The Politics of Global Regulation (Cambridge University Press, Cambridge, UK 2009); Gralf-Peter Calliess and Peer Zumbansen, Rough Consensus and Running Code: A Theory of Transnational Private Law (Hart Publishing, Oxford, UK 2010), 181, 242-247

199 Dan Danielsen, 'Local Rules and a Global Economy: An Economic Policy Perspective' (2010) 1 Transnational Legal Theory 49-115

${ }^{200}$ See, for example, the overview at www.ecgi.org, and www.transnationalcorporategovernance.net.

201 Johannes Köndgen, 'Privatisierung des Rechts. Private Governance zwischen Deregulierung und Rekonstitutionalisierung' (2006) 206 AcP 477-525; Thomas M.J. Möllers, 'Europäische Methoden- und 
look at today's corporate governance debates reveals two important aspects. One is the way in which the analysis of contemporary corporate governance regulation can help us become sensitive to the emerging, new framework within which corporate governance rules are evolving, a framework which is constituted by a combination of local and transnational actors and norms, connected through 'networks' and migrating standards. ${ }^{202}$ As reflected in the further expanding research on transnational regulatory areas ${ }^{203}$, the high degree of technicality of the regulatory subjects and the crucial role of expert committees in drafting applicable norms in considerable distance from formal legislative processes ${ }^{204}$ presents a formidable challenge to traditional, regulatory theories of law. ${ }^{205}$

As we begin to understand the emerging regulatory frameworks in highly specialized areas as an illustration of contemporary rule-making, we can appreciate the legal pluralist deconstruction of formal and informal legal orders in a new light. Building, on the one hand, on early legal-sociological work by Ehrlich ('living law') and Gurvitch ('social law'), we are prompted to revisit the core question of any sociology of law, namely how 'to investigate the correlations between law and other spheres of society. ${ }^{206}$ Expanding the spectrum, on the other, with a

Gesetzgebungslehre im Kapitalmarktrecht. Vollharmonisierung, Generalklauseln und soft law im Rahmen des Lamfalussy-Verfahrens zur Etablierung von Standards' (2008) Zeitschrift für Europäisches Privatrecht 480-505, 485; Peer Zumbansen, 'The Privatization of Corporate Law? Corporate Governance Codes and Commercial SelfRegulation' (2002b) Juridikum 136-145

202 See Nils Brunsson and Bengt Jacobsson, A World of Standards (Oxford University Press, Oxford/New York 2000).

203 For a recent overview, see the excellent collection in: Sanjeev Khagram and Peggy Levitt (eds), The Transnational Studies Reader. Intersections \& Innovations (Routledge, London 2008); see also Janet Joven Levit, 'Bottom-Up International Lawmaking: Reflections on the New Haven School of International Law' (2007) 32 Yale J Int'I L 393-420, and the contributions by Alexia Herwig, Perez, von Bernstorff, Ladeur and Scott \& Wai in: Christian Joerges, Inger-Johanne Sand and Gunther Teubner (eds), Transnational Governance and Constitutionalism (Hart Publishing, Oxford, UK/Portland, US 2004).

${ }^{204}$ David Vogel, 'Private Regulation of Global Corporate Conduct', above; Peer Zumbansen, 'Varieties of capitalism and the learning firm: corporate governance and labour in the context of contemporary developments in European and German company law' in Nina Boeger, Rachel Murray and Charlotte Villiers (eds), Perspectives on Corporate Social Responsibility (Edward Elgar, Cheltenham 2008)

205 Adrienne Héritier and Dirk Lehmkuhl, 'The Shadow of Hierarchy and New Modes of Governance' (2008) 28 Journal of Public Policy 1-17

${ }^{206}$ Eugen Ehrlich, Fundamental Principles of the Sociology of Law (orig. published in German as Grundlegung der Soziologie des Rechts, 1913) (Russell \& Russell, New York 1962), 486-506 "The Study of the living law"; Georges Gurvitch, Sociology of Law (orig. published in French as Problèmes de la sociologie du droit) (Routledge and Kegan Paul, London 1947); Max Rheinstein, 'Review: Two Recent Books on Sociology of Law [reviewing Timasheff's 'Introduction' and Gurvitch's 'Elements']' (1941) 51 Ethics 220-231, 221-2 
view to legal pluralist work by scholars such as Moore ${ }^{207}$, Galanter ${ }^{208}$, Macaulay ${ }^{209}$, de Sousa Santos $^{210}$ or Teubner ${ }^{211}$, contemporary assessments of "hybrid legal spaces' ${ }^{212}$ that are not sufficiently captured by references to local or national contexts, might help us understand better the references to a distinctly transnational emergence of regulatory regimes. Again, this identification of transnational allows us to study such regimes not as entirely detached from national political and legal orders, but as emerging out of and reaching beyond them. ${ }^{213}$ As alluded to before, the transnational dimension of new actors and newly emerging forms of norms would be able to radicalize their 'semi-autonomous' nature (Moore) in the following way: we would conceive of regulatory spaces as being marked by a dynamic and often problematically instrumentalized tension between formal and informal norm-making processes.

But, in contrast to the ever-refining sociological perspective on this evolving transnational regulatory landscape, the question of politics must continue to linger painfully. ${ }^{214}$ Again, an example taken from the corporate law context may serve as an illustration. The much lamented, regulatory 'failure' of traditional, state-based legal-political intervention into

${ }^{207}$ Sally Falk Moore, 'Law and Social Change: the semi-autonomous field as an appropriate subject of study' (1973) 7 Law \& Society Review 719-746

208 Marc Galanter, 'Justice in many rooms: Courts, Private Ordering and Indigenous Law' (1981) $19 \mathrm{~J}$ Leg Pluralism 1-47

${ }^{209}$ Stewart Macaulay, 'Private Government' in Leon Lipson and Stanton Wheeler (eds), Law and the Social Sciences (Russell Sage, Washington 1986)

${ }^{210}$ Boaventura de Sousa Santos, 'Law: A Map of Misreading. Toward a Postmodern Conception of Law' (1987) 14 Journal of Law \& Society 279

${ }^{211}$ Gunther Teubner, 'The Two Faces of Janus: Rethinking Legal Pluralism' (1992) 13 Cardozo Law Review $1443-$ 1462; Gunther Teubner, 'Societal Constitutionalism: Alternatives to State-Centred Constitutional Theory?' in Christian Joerges, Inger-Johanne Sand and Gunther Teubner (eds), Constitutionalism and Transnational Governance (Hart Publishing, Oxford, UK/Portland, OR 2004)

${ }^{212}$ Paul Schiff Berman, 'Global Legal Pluralism' (2007) 80 S Cal L Rev 1155-1237, 1155

${ }^{213}$ In a study of transnational private law with Gralf-Calliess, we have termed these 'transnational law regimes', see Gralf-Peter Calliess and Peer Zumbansen, Rough Consensus and Running Code: A Theory of Transnational Private Law (Hart Publishing, Oxford, UK 2010), 109-113.

${ }^{214}$ See only David Schneiderman, 'Transnational Legality and the Immobilization of Local Agency' (2006) 2 Annual Review of Law and Social Sciences 387-408, and Peter Fitzpatrick, 'Terminal Legality? Human Rights and Critical Being' in Peter Fitzpatrick and Patricia Tuitt (eds), Critical Beings Law, Nation and the Global Subject (Ashgate, Aldershot 2004) 
multinational corporations ( $\mathrm{MNC}$ ) has long served as an argument for the need to develop either distinctly 'post-national', institutionalized governance forms or to further strengthen the grip of self-regulatory and soft instruments with only voluntary binding nature. ${ }^{215}$ Mirroring the complex, hard-to-navigate landscape of border-crossing corporate activity, the proposed conceptual approaches vary greatly as to their reliance on self-regulation, market-based reputational enforcement and traditional statutory intervention. Constituting anything but a coherent set of applicable approaches to corporate regulation, they range from references to 'global jurisdiction' 216 , to the reconceptualisation of 'torture as tort' and the elaboration of transnational civil human rights litigation. ${ }^{217}$ Closely connected hereto, there have been wideranging efforts to further build on scandalization instruments that include global shaming. ${ }^{218}$ Finally, the increased if not resigned reliance on soft law instruments, self-binding norms, and codes of conduct and best practice ${ }^{219}$, altogether suggests an irreversible trend away from 'government' to 'governance'. 220

${ }^{215}$ Adelle Blackett, 'Global Governance, Legal Pluralism and the Decentered State: A Labor Law Critique of Codes of Corporate Conduct' (2001) 8 Indiana Journal of Global Legal Studies 401-447; Harry W. Arthurs, 'Reinventing Labor Law for the Global Economy: The Benjamin Aaron Lecture' (2001) 22 Berkeley Journal of Employment and Labor Law 271-294

${ }^{216}$ Paul Schiff Berman, 'Towards A Cosmopolitan Vision Of Conflict Of Laws: Redefining Governmental Interests In A Global Era' (2005) 153 U Pa L Rev 1819-1882

${ }^{217}$ Craig M. Scott, 'Introduction to Torture as Tort: From Sudan to Canada to Somalia' in Craig M. Scott (ed) Torture as Tort (Hart Publishing, Portland, OR/Oxford 2001); Craig M. Scott, 'Translating Torture into Transnational Tort: Conceptual Divides in the Debate on Corporate Accountability for Human Rights Harms' in Craig M. Scott (ed) Torture as Tort (Hart Publishing, Portland, OR/Oxford 2001)

${ }^{218}$ Andreas Fischer-Lescano, 'Globalverfassung, Verfassung der Weltgesellschaft' (2002) 88 Archiv für Rechts- und Sozialphilosophie [ARSP] 349-378

${ }^{219}$ Oren Perez, Ecological Sensitivity and Global Legal Pluralism (International Studies in Private Law Theory, Hart Publishing, Oxford/Portland, OR 2004)

${ }^{220}$ In that sense, 'governance' studies become more and more important in their cross-disciplinary inquiry into changing forms of political and legal regulation: see, for example, the research program of the University of Bremen's Collaborative Research Centre "Transformations of the State", at http://www.sfb597.uni-bremen.de/ 
As transnational governance regimes, then, fields such as corporate governance, labour law ${ }^{221}$, capital market law, contract law in general and consumer protection law in particular ${ }^{222}$ are increasingly marked by the existence of opt-out clauses and self-regulation mechanisms rather than by enforceable hard-law rules. ${ }^{223}$ Does this mean, that the legal pluralist depiction of regulatory spheres as 'semi-autonomous fields' ${ }^{224}$ would no longer be able to provide a sufficient starting point for a more comprehensive critique of the existing machinery of justice ${ }^{225}$ Does the radical fragmentation of transnational law today imply that the original legal pluralist sword is too dull to cut through the distinctly post-national constellation of regulatory regimes? The opposite is true: legal pluralism can forcefully build on its learned lessons in the aftermath times of the decaying welfare state and 'legal centralism'. While not being able to directly translate the insights gained in those contexts onto the transnational sphere, they can nevertheless assist in depicting the multifaceted nature of transnational governance. This becomes particularly evident where, in a context such asan evolving political governance system such as in Europe, claims about 'private autonomy' and 'market freedom' are advanced $^{226}$ that seem to echo many of the previous contestations of market intervention and judicial activism within the nation state. ${ }^{227}$ Our renewed interest in different meanings of

${ }^{221}$ Alain Supiot, Au-delà de l'emploi. Transformation du travail et devenir du droit du travail en Europe. Rapport pour la Commission européenne. (Flammarion, Paris 1999); Robert O'Brian, 'The difficult birth of a global labour movement' (2000) 7 Rev Int'I Pol Econ 514-523; Claire Methven O'Brien, 'Reframing Deliberative Cosmopolitanism: Perspectives on Transnationalisation and Post-national Democracy from Labor Law' (2008) 9 German Law Journal 1007-1042

${ }^{222}$ Gralf-Peter Calliess, 'Reflexive Transnational Law. The Privatisation of Civil Law and the Civilisation of Private Law' (2002) 23 Zeitschrift für Rechtssoziologie 185-216; Gralf-Peter Calliess, Grenzüberschreitende Verbraucherverträge. Rechtssicherheit und Gerechtigkeit auf dem elektronischen Weltmarktplatz (Jus Privatum, Mohr Siebeck, Tübingen 2006)

${ }^{223}$ Walter Mattli and Ngaire Woods, 'In Whose Benefit? Explaining Regulatory Change in Global Politics' in Walter Mattli and Ngaire Woods (eds), The Politics of Global Regulation (Cambridge University Press, Cambridge, UK 2009)

${ }^{224}$ Sally Falk Moore, 'Law and Social Change: the semi-autonomous field as an appropriate subject of study' (1973) 7 Law \& Society Review 719-746; John Griffiths, 'What is Legal Pluralism?' (1986) 24 Journal of Legal Pluralism and Unofficial Law 1-55; Sally Engle Merry, 'Legal Pluralism' (1988) 22 Law \& Society Review 869-901

${ }^{225}$ John Griffiths, 'What is Legal Pluralism?' (1986) 24 Journal of Legal Pluralism and Unofficial Law 1-55

${ }^{226}$ For a brillant discussion, see Daniela Caruso, 'Private Law and Public Stakes in European Integration: the case of Property' (2004) 10 European Law Journal 751-765, and Christian Joerges, 'The Challenges of Europeanization in the Realm of Private Law: A Plea for a New Legal Discipline' (2004) 14 Duke J Comp \& Int'I L 149-196.

227 Robert L. Hale, 'Coercion and Distribution in a Supposedly Non-Coercive State' (1923) 38 Political Science Quarterly 470-494; Eric A. Posner, Law and Social Norms (Harvard University Press, Cambridge, MA \& London, UK 2000) 
embedded markets is of crucial importance at a time when the financialist paradigm seems to have outrun itself and where, in our search for a new basis and framework for public policy ${ }^{228}$ in a highly interconnected transnational regulatory, post Welfare-state era, we cannot simply return to 'more state, less market' formulas. The crucial contribution of a legal pluralist analysis lies in its rendering the boundaries between the state and the market qualititative rather than quantitative. The central question is not whether there is a need for more or less state (or market), but rather what is at stake in making references to either?

The following Table 3 picks up this line of thought and ties it back to the narrative of loss (of legal unity, certainty and hierarchy) that we encountered at the beginning of this article. While the idea of loss only makes sense when we both idealise and immunise law in the nation state against its inherent 'other', the consequence of realising that we must think of law as the inseparability of law/non-law is a breaking down of the horizontal boundaries between 'national' and 'global' law. Just as the boundary between law and non-law emerges as paradoxical, the dividing line between the national and the global is not one governed by jurisdiction. It is, instead, one that relies on a critical reconstruction of the project of law - and, as noted earlier, we embrace "transnational law" as a methodological project on the very nature of normativity generally and law more particularly. The much alleged impossibility of law on a global scale must become the invitation to revitalize the legal pluralist project of questioning what is at stake when we differentiate between law and non-law. This is the defining inquiry into the nature of transnational governance.

\footnotetext{
228 Alexander Ebner, Governance and Public Policy: Polanyi's Theory of Public Policy: Embeddedness, Commodification and the Institutional Dynamism of the Welfare State (Staatswissenschaftliche Fakultät, Erfurt 2008)
} 
Table 3: Law as Non-Law - Transnational Legal Pluralism

\begin{tabular}{|c|c|c|}
\hline & LAW & NON-LAW \\
\hline NATIONAL & $\begin{array}{l}\text { Legal unity } \\
\text { Institutionalised change of law } \\
\text { (Consumer Law, Employment Law, } \\
\text { Constitutional Law) } \\
\text { Hierarchy of norms } \\
\text { Separation of powers } \\
\text { Access to justice } \\
\text { Due process }\end{array}$ & $\begin{array}{r}\bullet \text { Sociology of law } \\
\bullet \text { Legal pluralism } \\
\text { - Deconstruction of (formal) Law } \\
\bullet \text { Law's 'other' } \\
\text { - The not-yet law as critique of existing law } \\
- \text { 'Social norms' } \\
\text { Non-law as alternative }\end{array}$ \\
\hline GLOBAL & $\begin{array}{l}P_{\text {Quasi-political, }} \text { Transnatic } \\
\text { quasi-public regulatory agencies } \\
D_{\text {Calls for a just global order }} \\
D_{\text {Search for post-national }} \\
\text { legitimacy }\end{array}$ & nal Legal Pluralism \\
\hline
\end{tabular}

\section{The Argument for Transnational Legal Pluralism}

As Saskia Sassen has recently reiterated, both dryly and irrefutably, there is an intimate connection between the search for and the critique of law and the nation state. ${ }^{229}$ Her observation is particularly astute as Sassen has, over the years ${ }^{230}$, much contributed to our better understanding of how the allegedly external, victimising state of 'globalisation' is

\footnotetext{
${ }^{229}$ Saskia Sassen, Territory - Authority - Rights. From Medieval to Global Assemblages (Princeton University Press, Princeton, NJ/Oxford, UK 2006), 1: "We are living through an epochal transformation, one as yet young but already showing its muscle. We have come to call this transformation globalization, and much attention has been paid to the emerging apparatus of global institutions and dynamics. Yet, if this transformation is indeed epochal, it has to engage the most complex institutional architecture we have ever produced: the national state."
}

${ }^{230}$ See, for example, Saskia Sassen, The Mobility of Labor and Capital. A Study in international investment and labor flow (Cambridge University Press, Cambridge u.a. 1988); Saskia Sassen, The Global City (Princeton University Press, Princeton 1991); Saskia Sassen, Globalization and Its Discontents. Essays on the New Mobility of People and Money (The New Press, New York 1998); Saskia Sassen, 'Globalization or denationalization?' (2003) 10 Review of International Political Economy 1-22; Saskia Sassen, 'The City: Its Return as Lens for Social Theory. Keynote presentation at the International Conference for Integrating Urban Knowledge \& Practice, Gothenburg, Sweden, May 29 to June 5, 2005' (2005) http://wwwurbanlife2005com/proceedings/keynotes/Saskia_Sassenpdf 
distinctly co-evolving with and produced, constructed and conceived within the 'national'. Instead of positing globalisation as a process, event or development that comes over nation states, national economies and domestic political processes to haunt, discipline and submerge, Sassen's depiction - like Sousa Santos' ${ }^{231}$ - points back to the nation state and to sub-national spheres of societal activity and decision-making. It is within these spheres that elements of physical and intellectual texture emerge that coalesce to produce border-crossing 'global assemblages'. These constitute distinct spheres that, famously fuelled by, inter alia, the dramatic development of information technology and other 'transnational social and cultural practices' such as human rights, nationality and residence rights as well as intellectual property rights $^{232}$, integrate territorial and de-territorial, vertical and horizontal ordering patterns to produce a structured regime of societal activities. ${ }^{233}$

Sassen's concept of 'global assemblages' constitutes a fruitful contribution to our understanding of globalisation as a challenge to study the dramatic transformation of institutional and semantic structures in an era of intensifying transnational communication and governance regimes.

Sassen's idea of global assemblages allows us to structure the sphere between the national and the international/global that has been plaguing legal imagination for some time now. ${ }^{234}$ Her main contribution can be seen in her unerring commitment to simultaneously emphasise and relativise the national in the emerging cartography of a globalised world. Sassen's emphasis on the national and sub-national, viz. local, processes and institutions goes a long way toward allowing us to identify the concrete places at which decisions that result in globalisation phenomena are prepared, taken and implemented. Her work on global cities is of particular relevance in this regard. Here, Sassen has been arguing convincingly that global cities gain autonomy from their local environments both by adapting real-time collaborative and networking capacities with other cities and operative centres and by successfully demanding and implementing a facilitating, supportive infrastructure (electricity, broadband, digitisation,

231 Boaventura de Sousa Santos, 'The Processes of Globalisation' (2002) Eurozine http://www.eurozine.com/pdf/2002-2008-2022-santos-en.pdf, 17: “Globalisation results, in fact, from a set of political decisions which are identifiable in time and authorship. The Washington Consensus is a political decision of the core states, as are the decisions of the states which adopted it with a greater or lesser degree of autonomy and selectivity. We cannot forget that, to a great extent, and above all on an economic and political level, hegemonic globalisation is a product of the decisions of national states."

${ }^{232}$ Sousa Santos, preceding note, at 22

${ }^{233}$ Saskia Sassen, Territory - Authority - Rights. From Medieval to Global Assemblages (Princeton University Press, Princeton, NJ/Oxford, UK 2006)

${ }^{234}$ Gunther Teubner (ed), Global Law Without A State (Ashgate, Aldershot 1997) 
$24 / 7$ service, access and maintenance). ${ }^{235}$ At the same time, to Sassen, the depiction of the particular 'embeddedness' of the global city in a local environment only makes sense in connection with an appreciation of the particular spaces that open up in and between these concrete cities as places. Highlighting, in particular, the crucial role played by the breathtaking advances in information technology that fuel the space-time compression through real-time collaboration, connection, and linking of formerly distant places, actors and centres, Sassen, then and now ${ }^{236}$, recognises the central challenge that these changes place on the "effectiveness of current framings for state authority and democratic participation." 237 Spaces in Sassen's understanding, then, are not to be mistaken with territorially or geographically defined 'areas', but constitute much more ambiguous realms that are constituted through societal interaction as well as through intellectual construction. Examples include 'global cities and transboundary publics ${ }^{238}$ but also global capital markets ${ }^{239}$, which illustrate how the triad of 'territory, authority, rights' is inescapably subjected to increasingly denationalised processes of deassembling and reassembling. ${ }^{240}$

The relativisation of the national basis of globalisation in Sassen's work proceeds in relation to the well-known institutions, reference points and established procedures such as states, parliaments, administrative agencies and, importantly, courts. Those have long structured the economic, political and legal order and are now struggling to re-assert their previously held roles and positions of power. ${ }^{241}$ This - relative - relativisation of the national feeds into the

${ }^{235}$ For a concise restatement of her long-term, monographical work on global cities, see Saskia Sassen, 'The Global City' in Susan Fainstein and Scott Campbell (eds), Readings in Urban Theory (Blackwell, Malden, MA/Oxford, UK 1999).

${ }^{236}$ Sassen (2006)

${ }^{237}$ Saskia Sassen, Territory - Authority - Rights. From Medieval to Global Assemblages (Princeton University Press, Princeton, NJ/Oxford, UK 2006), 328

${ }^{238}$ Saskia Sassen, 'Globalization or denationalization?' (2003) 10 Review of International Political Economy 1-22, 6

239 Saskia Sassen, 'The Embeddedness of Electronic Markets: The Case of Global Capital Markets' in Karin Knorr Cetina and Alex Preda (eds), The Sociology of Financial Markets (Oxford University Press, Oxford, UK/New York, NY 2005)

${ }^{240}$ Saskia Sassen, Territory - Authority - Rights. From Medieval to Global Assemblages (Princeton University Press, Princeton, NJ/Oxford, UK 2006), 6: "Today, particular elements of TAR [territory, authority, rights, PZ] are becoming reassembled into novel global configurations. Therewith, their mutual interactions and interdependencies are altered as are their institutional encasements."

241 See also Anne-Marie Slaughter, 'Disaggregated Sovereignty: Towards the Public Accountability of Global Government Networks' (2004) 39 Government and Opposition 159-190. 
formation of a newly emerging spatial category: the focus on space promises to capture more adequately the way in which our understanding of regulatory landscapes as well as of scopes of human interactions still reckons with concretely identifiable places of legal and political regulation while at the same time reaching beyond it. While the latter is aptly depicted in both Sassen's and de Sousa Santos' analysis of the interaction between the national and the global, the former has been given a powerful expression by David Levi-Faur's concept of 'regulatory capitalism' ${ }^{242}$ This constellation presents tremendous challenges to both an analytical and prescriptive framework that was developed with reference to a more or less well defined, territorially confined and institutionally closely-knit regulatory framework. ${ }^{243}$ To be sure, one challenge of this embrace of space consists in developing an appropriate language with which to communicate about the institutional and normative challenges in a world that cannot effectively be governed through domestic and domestically minded rules. ${ }^{244}$ The other challenge arises from the intricate nature of the spaces unfolding in the transnational realm. Part of the reason for the Washington Consensus' effectiveness in streamlining - literally on a global scale - regulatory politics, has to be seen in the particular connections and interdependencies that were created between, say, corporate, tax, labour, financial and social regulation. Bound to upset and to undermine fragile balances between different social interests, the deregulation of corporate, commercial and financial activity gave rise to an overwhelming amount of new regulatory institutions and instruments ${ }^{245}$, all the while promoting a principle of 'good governance' marked by minimum state intervention into allegedly self-regulating markets. Among the primary victims, surely, was and remains labour, as regards both the differently institutionalised forms of workers' protection, industrial relations and collective bargaining and the sobering erosions of basically all forms of employment security. A far cry from Polanyi's succinct critique of Speenhamland ${ }^{246}$ and

242 David Levi-Faur, 'The Global Diffusion of Regulatory Capitalism' (2005) 598 The Annals of The American Academy of Political and Social Science 12-29; see also John Braithwaite, Regulatory Capitalism. How it Works, Ideas for Making it Work Better (Edward Elgar, Cheltenham, UK 2008).

${ }^{243}$ Saskia Sassen, 'Globalization or denationalization?' (2003) 10 Review of International Political Economy 1-22, 7: "Older hierarchies of scale constituted as part of the development of the nation-state, continue to operate, but they do so in a far less exclusive field than they did in the recent past."

244 See already Rudolf Wiethölter, 'Begriffs- oder Interessenjurisprudenz - falsche Fronten im IPR und Wirtschaftsverfassungsrecht' in Alexander Lüderitz and Jochen Schröder (eds), Internationales Privatrecht und Rechtsvergleichung im Ausgang des 20 Jahrhunderts (Alfred Metzner Verlag, Frankfurt 1977).

245 David Levi-Faur, 'The Global Diffusion of Regulatory Capitalism' (2005) 598 The Annals of The American Academy of Political and Social Science 12-29, 15: "Moreover, new regulatory institutions, technologies, and practices are increasingly embedded in the crowded and complex administrative structures of modern capitalist nation-states." See also id., at 19: "...regulation is helping to legitimize markets and facilitate transactions by enhancing trust."

${ }^{246}$ Karl Polanyi, The Great Transformation. The Political and Economic Origins of our Time (Beacon Press, Boston 1944). 
Arendt's meditations on the transformation of the worker into a political actor ${ }^{247}$, the rise of the 'precariat' ${ }^{248}$ has been accompanied by an across-the-board undermining of both institutional and individual frameworks of workers' rights. ${ }^{249}$ Conceptual approaches such as democratic experimentalism ${ }^{250}$, regulatory capitalism or transnational labour citizenship ${ }^{251}$ constitute attempts towards the development of an appropriately designed framework of legal analysis and regulation in light of a radically disembedded regulatory landscape.

The above can be seen as one of many more present examples that illustrate how the specifically European Post-Westphalian legal perspective, which predominantly rested on an understanding of a hierarchically structured system of order, ${ }^{252}$ has, within the confines of the nation-state and later in light of a fast-proliferating realm of border-crossing hybrid regulatory activity, been put on the defensive. Much in the present discussions about the fate of law in an era of globalisation is oriented around the form, nature and quality of a global legal order. ${ }^{253}$ Yet, as captured in Table 3, such investigations remain for the most part confined to an analysis on the left hand side of the matrix, namely to an exercise in contrasting the presently perceived absence of reliable legal institutions and instruments on the global scale with an allegedly perished state of legal certainty, hierarchy of norms and the unity of law within the nationstate. It is only when we care to remember the description of the legal order from a legal pluralist point of view that the fundamental fragility of the supposedly stable and unified legal system becomes again apparent. Once we revisit the pluralist contestation of law's exclusivity and its alleged hierarchical supremacy within the nation state, we begin to see the transition

${ }^{247}$ Hannah Arendt, The Human Condition (Chicago University Press, Chicago 1958)

${ }^{248}$ Guy Standing, Work After Globalization (Edward Elgar, Cheltenham, UK 2010)

249 Harry Arthurs and Claire Mummé, 'From Governance to Political Economy: Insights from a Study of Relations between Corporations and Workers' (2007) 45 Osgoode Hall Law Journal 439-470; Kerry Rittich,'Vulnerability at Work: Legal and Policy Issues in the New Economy. Report for the Law Commission of Canada' (Faculty of Law, University of Toronto, Toronto 2004)

${ }^{250}$ Michael C. Dorf and Charles F. Sabel, 'A Constitution of Democratic Experimentalism' (1998) 98 Columbia Law Review 267-473

${ }^{251}$ Jennifer Gordon, 'Transnational Labor Citizenship' (2007) 80 Southern California Law Review 503-587

252 Nils Jansen and Ralf Michaels, 'Private Law and the State. Comparative Perceptions and Historical Observations' (2007) 71 Rabels Zeitschrift für ausländisches und internationales Privatrecht [RabelsZ] 345-397

253 See for this only the still excellent exposition of the interdisciplinary nature of globalization studies: David Held and Anthony McGrew (eds), The Global Transformations Reader. An Introduction to the Globalization Debate (2000), 2nd ed. (Polity, London 2003), Introduction. 
from a nation state-based understanding of law towards one of 'global law' as a continuation rather than as a loss -- of a theoretical investigation into the meaning of law and legal ordering. It is this perspective that should drive lawyers' interest in the present musings about 'space'.

The lawyer struggling to understand the fate of her field in a world of transition from national to global is bound to engage in a both methodological and theoretical inquiry. It is methodological in the sense that legal concepts are competing with alternative disciplinary approaches to effectively address the regulatory challenges and goals arising from 'global governance'. It is theoretical in the sense that the widely observable proliferation of norm creation and norm administration in numerous areas of what legal scholars and political scientists have been coining 'private transnational regulation' ${ }^{254}$ prompts a revisiting of the 'concept' of law. But, in addition, the claims laid to this space are fiercely driven by political, religious, cultural and 'social' critique. What is at stake in fact is less an answer to the question whether or not the norms in question are law. Such questions were relatively easily posedand answered-in the context of the fairly differentiated legal systems of Western welfare states, in which distinctions between public and private ordering could usually be drawn by reference either to the larger societal interest in question or to the institutional affiliation of the norm's author, in other words the 'authority' of the norm entrepreneur. In the transnational space, this institutional framework is being fundamentally reshaped. The constitutional order, on the basis of which it was possible in Western nation states to constantly scrutinise and redraw the boundaries between public and private regulatory activity, is largely absent in the transnational space. Instead, process-oriented principles such as accountability and transparency are mobilised and implemented in a vast array of transnational norm creations in order to fill this void. At the heart of such attempts-as in the 'Global Administrative Law' project-is the struggle over a new foundation of legitimacy. Again, moving out of the highly regulated space of the nation state, the struggle over legitimacy becomes one of deep-running conflicts and the various competing attempts to solve them. As such, for lawyers and their field, the reference to 'space' is first and foremost a reminder of the fragility of their conceptual framework and their regulatory instruments.

What, then, follows from this constellation for the lawyer and legal theory? Included in the resulting task for the lawyer in his/her quest to reassess the nature of global legal regulation is the need to scrutinise and explore both the obvious and not so obvious differences between law and competing regulatory approaches that are on offer in a globalising world, for example, from economics, religion, or 'culture'. The lawyer will tend to distinguish her project from those competitors in both formal and substantive dimensions. As regards form, the primary mark of distinction that she will resort to is hierarchy, for what sustains the typical lawyer is the belief in a system of social order that is built on a model of legitimate authorisation, based on which are

${ }^{254}$ www.privateregulation.eu. 
rules of norm creation, implementation and enforcement. ${ }^{255}$ In terms of substance, the demarcation between law and alternative forms of social order can be drawn with reference to the centrality of 'justice' to the legal system. Yet, it soon becomes clear that the selfreferentiality of justice in the legal system ${ }^{256}$ is echoed and paralleled by similar, even if differently called, self-references in other systems. Law's claim to be the sole guardian of really any concept of justice, in other words of justice 'per se', cannot in the end escape its deconstruction as pure semantics.

Law's relativisation, then, in the concert of differently conceived 'governance' models, is a sobering prospect. At the same time, it is one that seems distressingly compatible with the long-time triumphant neo-liberal assertions of law's role in facilitating global market activity and universal freedom - from, say, state intervention. If law were really not more than a different label for 'good governance', it would indeed have little if anything to add to the current investigations into the consequences of globalisation. That is why the lower right hand corner of the matrix in Table 3 becomes an important final step in the attempt to picture the nature and the fate of law in our time. This part of the matrix depicts the global illustrations of the contestation of legal order and of its claims to supremacy, hierarchy, unity and universality. The decisive step in making sense of the matrix now is to ask how the inherently contestable, amorphous, incoherent and not fully articulable principles, rules and instruments that emerge here can at all turn into law. In other words, how can concepts such as 'transnational labour citizenship', 'global civil society' or 'global administrative law' become integral components of a global order, which we would justly refer to as a legal order?

The answer lies in the connection between the upper and the lower parts of the right-hand column of the matrix. For, on the level of the nation state, we saw the dissolution of the vertical boundary between 'law' and 'nonlaw' as a result of understanding that none of the principles, rules, instruments or institutions associated with law (the upper left hand side of the matrix) would exist without the 'other', without the contestation, constant undermining and challenge of the existing system of 'law'. Two steps remain: one is that when we apply this logic to the lower side of the matrix through which we try to depict the 'global' scale of law, then it becomes apparent that the vertical boundary between 'law' and 'nonlaw' must cease, as it, too, is a misrepresentation of the reciprocal interdependency of the right and the left sides of the divide. Indeed, the very fluid character of emerging global 'legal' institutions must occur in face of the fundamental challenge and contestation of all that is not or not yet law.

\footnotetext{
255 Helmut Willke, Smart Governance. Governing the Global Knowledge Society (Campus, Frankfurt/New York 2007), who highlights law's hierarchical structure as the defining difference to economic models of order.

256 Niklas Luhmann, Ausdifferenzierung des Rechts. Beiträge zur Rechtssoziologie und Rechtstheorie (Suhrkamp, Frankfurt 1981)
} 
The last step: now with the dividing line between 'law' and 'nonlaw' on both the national and the global level revealed as a paradoxical boundary between two opposites which can neither be separated nor become one, we are left with the remaining divider between the national and the global. The nature of that divide has itself, however, become deeply questionable as well. One of its main justifications, namely law's close association with the state, has been challenged to the degree that legal pluralism has opened our eyes to a host of normative orders and contexts of legal ordering with forms of institutionalisation that do not fit into the dualist model of state and society. Moreover, legal fields that lawyers had identified and scrutinised within the confines of the nation state, have been - in following the logic of the societal areas prompting legal regulation - burgeoning 'outward', as it were, driven by the claim to 'extend' their regulatory reach to border-crossing and, indeed, global events and activities. But, with law following the rationality of societal differentation, the image of law's outbound journey into a world of global meaning is misleading. This journey could just as well be described as an inbound one, as an exploration that unfolds along the extremely fine capillaries of a convulsing body of society into its deepest inner parts and, there, asserts its logic of 'legal' and 'illegal'. In light of influential images of a 'shrinking world'257, globally spanning migration flows ${ }^{258}$, media coverage of formerly distant events and concerns ${ }^{259}$ and a deafening expansion of a global culture $^{260}$, it is often perceived that the law has in fact been under pressure to travel 'beyond' the boundaries of the nation state, to assert and to regain its regulatory power in an otherwise unruly global world. And in fact, developments under the label of legal globalisation have taken on a wide range of forms, from local courts claiming 'universal' jurisdiction ${ }^{261}$ to the development of behaviour-guiding norms in the forms of codes of conduct, best practice guidelines or recommendations, which can themselves no longer be conceived of as either public or private, national or international law.

${ }^{257}$ Martin Wolf, Why Globalization Works (Yale University Press, New Haven, CT 2004)

258 Catherine Dauvergne, Making People Illegal: What Globalization Means for Migration and Law (Cambridge University Press, Cambridge, UK 2008)

${ }^{259}$ For an excellent analysis, see Andreas Fischer-Lescano, 'Die Emergenz der Globalverfassung' (2003) Zeitschrift für ausländisches öffentliches Recht und Völkerrecht [ZaöRV]

${ }^{260}$ For a critique, see Arjun Appadurai, 'Disjuncture and Difference in the Global and Cultural Economy' (1990) 2 Public Culture 1-24.

${ }^{261}$ For an astute discussion and analysis, see Hannah Buxbaum, 'National Courts, Global Cartels' (2004) 5 German Law Journal 1095-1106, Hannah L. Buxbaum, 'National Jurisdiction and Global Business Networks' (2010) 17 Indiana Journal of Global Legal Studies 165-181, and Paul Schiff Berman, 'The Globalization of Jurisdiction' (2002) 151 University of Pennsylvania Law Review 311-545. 
It is this diffusion of normative orders in the form of proliferating norm producers and enforcement schemes that seriously calls into question the dividing line between a national and a global level of law making. Indeed, as mentioned above, many of today's regulatory regimes combine public and private, direct and indirect forms of norm creation and administration. These 'transnational law regimes' ${ }^{262}$ emerge, on the one hand, through actors who derive their law making power not necessarily or exclusively from politically and formally institutionalised hierarchies but increasingly from self-legitimating, issue or problem-area driven processes of norm production and from a global flow of normative principles, institutional initiatives, 'migrating principles' ${ }^{263}$ and norms, on the other.

The central argument to be made here is that we must conceive of this transformation and erosion of the vertical (law/nonlaw) and horizontal (national/global) boundaries as a methodological inquiry into the way in which spaces of legal order are being defined. The legal pluralist project of the $20^{\text {th }}$ century in many ways opened the door to a harsh, often very empirically based, critique of the shortcomings and blindspots of existing, formally institutionalised legal cultures. The legal pluralists pushed for a theorisation that involved applying legal sociological insights gained in foreign, often indigenous, legal cultures to domestic rule of law systems, eventually paving the way for a tremendously rich series of investigations into the inner and outer worlds of different legal cultures. ${ }^{264}$ The present state of research on 'law and globalisation' suggests that the demarcation of national and global forms of law today is as much a methodological (and critical enterprise) as the legal pluralist deconstruction of legal hierarchy and unity of law was then.

Transnational law is another name for transnational legal pluralism, for an - inherently interdisciplinary - inquiry into the nature of legal regulation of problems, which have long been extending beyond the confines of jurisdiction - both 'inside' and 'outside' of the nation state ${ }^{265}$

\footnotetext{
262 Gralf-Peter Calliess and Peer Zumbansen, Rough Consensus and Running Code: A Theory of Transnational Private Law (Hart Publishing, Oxford, UK 2010)

${ }^{263}$ See eg the contributions to Sujit Choudhry (ed), The Migration of Constitutional Ideas (Cambridge University Press, Cambridge 2006).
}

\footnotetext{
${ }^{264}$ See eg the analysis by Mariana Valverde, Law's Dream of a Common Knowledge (The Cultural Lives of Law, Princeton University Press, Princeton, NJ/Oxford, UK 2003); Susan G. Drummond, Mapping Marriage Law in Spanish Gitano Communities (UBC Press, Vancouver 2005); see also Craig M. Scott, "Transnational Law' as ProtoConcept: Three Conceptions' (2009) 10 German Law Journal 859-876, 874-5: "Law as both social practice and animating ideal may well be constructed and continue to exist independently of 'official law'. Indigenous property law, the relations of Moroccan and Spanish fishers in the middle of the Straits of Gibraltar, church law, Gitano marriage ritual, the principles of lending in the Shar'ia, 'internal' corporate norms, commercial custom in all its varieties, the complex normative nature of Internet regulation, the certification process of the Forest Stewardship Council, the guidelines produced by the International Union for Conservation of Nature, and so on."

${ }^{265}$ Richard Ford, 'Law's Territory (A History of Jurisdiction)' (1999) 97 Michigan Law Review 843
} 
-- and which have always been at the heart of the socio-legal orientation of the legal pluralist inquiry into the myriad contexts, forms and dynamics of norm creation. ${ }^{266}$ But, as the transnational legal pluralist project takes seriously the functional differentiation of a society in search of its law, it is bound to suggest and to explore connections between the law/nonlaw collisions then and now, and between those here and those 'out there'. And so, in trying to make sense of the changing frameworks of legal regulation for global human conduct and societal development, the transnational legal pluralist is bound to revisit former instances of legal realism, anti-formalism, functionalism, deconstruction and 'political legal theory'. But, the insights and lessons to be gained from this reconstruction are both limited and risky. Too often will the learned understandings of 'rights', of hierarchy or equality make the pluralist blind to the particular dynamics that govern a normative field. ${ }^{267}$ In response, transnational legal pluralism as a methodology implies a radical unfolding of the tension between the four different parts of the matrix. The law of a highly differentiated world society can neither be based on the rigid separation of law and nonlaw nor on a distinction between national and global. Instead, the transnational legal pluralist project highlights the evolution of legal categories that can generate order under circumstances where the traditional institutional framework and reference sets have to be seen as contingent. Such an evolution is part of a process of contending forces and dynamics with unpredictable outcomes. Existing and emerging research on regulatory regimes and regulatory governance as umbrella concepts for an interdisciplinary approach to the study of law and regulation points to the need to better connect seemingly disparate research and policy agendas. There are important parallels, say, between the legal pluralist critique of regulatory law on the one hand and the investigations in economic sociology into the evolving nature of the embeddedness of markets. ${ }^{268}$

Other parallels exist between the progressive methodological orientation of responsive/reflexive law in the 1970 s and 1980 s and 'cosmopolitanism' today ${ }^{269}$ on the one

\footnotetext{
${ }^{266}$ Craig M. Scott, "Transnational Law' as Proto-Concept: Three Conceptions' (2009) 10 German Law Journal 859876, 875: "...much of the transnationalizing world of law is 'transnational law' in the sense of not being statist in any strong way as well as in the sense of involving multiple actors (who admittedly may owe their legal existence to state and interstate legal orders but who are nonetheless neither states nor interstate entities. [...] For want of a better term at present, let us say this third approach involves a school of transnational socio-legal pluralism."
}

267 See already Günter Frankenberg, 'Critical Comparisons: Re-Thinking Comparative Law' (1985) 26 Harvard International Law Journal (Harv Int'I L) 411-455

${ }^{268}$ See Richard Swedberg, 'The Economic Sociology of Capitalism: An Introduction and Agenda' in Victor Nee and Richard Swedberg (eds), The Economic Sociology of Capitalism (Princeton University Press, Princeton, NJ 2005); see also the contributions in "The Embedded Firm: Labour, Corporate Governance and Finance Capitalism" (Peer Zumbansen \& Cynthia Williams eds., forthcoming)

269 Stephen Toulmin, Cosmopolis. The Hidden Agenda of Modernity (Free Press, New York 1990); Boaventura de Sousa Santos, 'The Processes of Globalisation' (2002) Eurozine http://www.eurozine.com/pdf/2002-2008-2022santos-en.pdf, 27: “...cosmopolitanism is only possible in an interstitial way on the margins of the world system in 
hand, and the recent, politically much more ambivalent interest in 'social norms' on the other. ${ }^{270}$ For each of these inquiries, a first task consists in continuing or opening and pursuing dialogues between law and economics, law and sociology, law and anthropology, law and political economy. A second task consists in effectively connecting the domestically unfolded critique of law under various guises - notably, that of legal realism, critical legal studies, law and economics, feminist legal studies or critical race theory, postcolonialism or Third World Approaches to International Law [TWAIL], of responsive, reflexive law, as well as social norms with, say, current debates around global governance, 'global administrative law', regulatory networks or transnational law. While we are not coming to such analysis without baggage, the challenge remains how to best apply the things learned and the things discovered in face of an extremely pluralistic and contested landscape. Beginning with neither taking law for granted nor mourning its death might provide a promising starting point for an analysis of legal regulation and its alternatives in a changing world.

transition as an anti-hegemonic practice and discourse generated by progressive coalitions of classes or subordinate social groups and their allies."

${ }^{270}$ See only the contributions to John N. Drobak (ed), Norms and the Law (Cambridge University Press, Cambridge 2006). 